Journal of the Scientific Agricultural Society of Finland

Vol. 49: 107-166, 1977

Maataloustieteellinen Aikakauskirja

\title{
THE EFFECT OF SOME GRAM-NEGATIVE BACTERIA ON THE RIPENING AND QUALITY OF DRY SAUSAGE
}

Selostus: Eräiden gram-negatiivisten bakteerien vaikutus kestomakkaran kypsymiseen ja laatuun

E S K O P E T Ä J Ä

Institute of Meat Technology, University of Helsinki Viikki, 00710 Helsinki 71, Finland

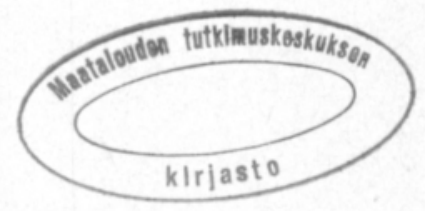

TO BE PRESENTED, WITH THE PERMISSION OF THE FACUlty OF Agriculture AND Forestry of the UNIVERSITY OF HELSINKI, FOR PUBLIC CRITICISM At Virkki in Auditorium E on September 23, 1977 Aт 12 o'cLock. 



\section{Acknowledgements}

I express my sincere thanks to Prof. F. P. Niinivaara, the head of the Institute of Meat Technology, University of Helsinki, for his encouragement and interest in this investigation.

For technical assistance I express my thanks to Miss Irma Hukkala and Mrs Pirkko Kostamo. To Mrs Aira Kuparinen and Mrs Anna-Maija Ullstedt, who assisted with the typing, my cordial thanks. I also extend my thanks to Olavi Kaitila and Jorma Outinen for their help in manufacturing the sausages.

To Prof. Esko Nurmi, the head of the State Veterinary Medical Institute, and Kyllikki AlaHuikku, Lic. vet. med. I extend my thanks for carrying out the mouse experiments to test the apathogenicity of the strains used in the investigation.

Some of the strains used in the research were received from Rudolf Müller \& Co. for which I am grateful.

My colleagues at the Institute of Meat Technology have been interested in this work and have given their help on many occasions during the investigation. I would like to express my gratitude for this assistance.

To Suomen Maataloustieteellinen Seura (the Scientific Agricultural Society of Finland) I extend my thanks for including this study in their series of publications.

I am grateful to The English Centre for checking the language of this work.

Finally I would like to dedicate this work to Kaarina, Pasi and Jussi for their help and contributions during my research.

Helsinki, September 1977 



\section{CONTENTS}

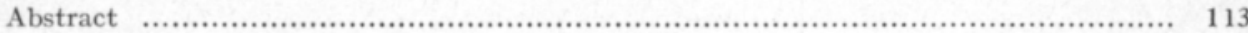

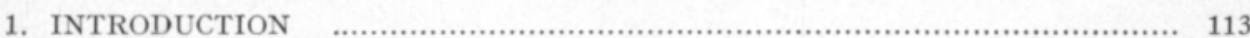

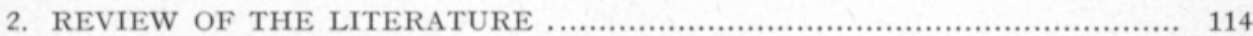

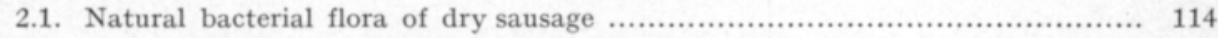

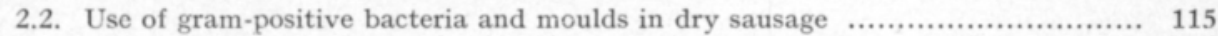

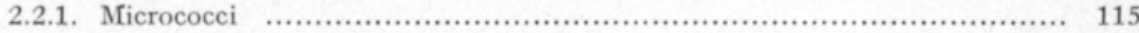

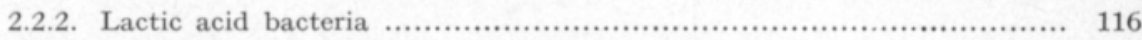

2.2.3. The mixture of micrococci and lactic acid bacteria $\ldots \ldots \ldots \ldots \ldots \ldots \ldots \ldots \ldots, 117$

2.2.4. Bacilli ..................................................................... 119

2.2.5. Moulds ............................................................................ 119

2.3. Gram-negative bacteria and their use in fermented meat products ............. 119

2.3.1. Taxonomy ...................................................................... 119

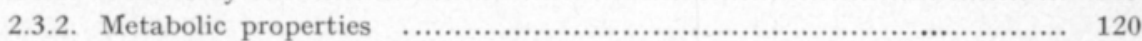

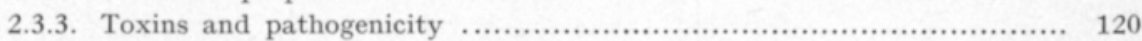

2.3.4. Gram-negative bacteria in meat curing ................................... 121

2.3.5. Gram-negative bacteria in the preparation of dry sausage $\ldots \ldots \ldots \ldots \ldots \ldots \ldots . \ldots \ldots 22$

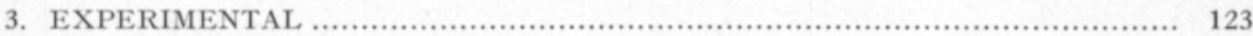

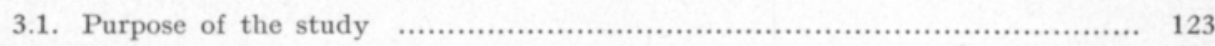

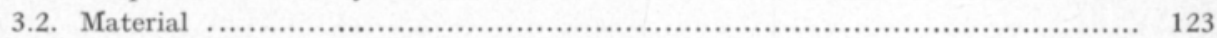

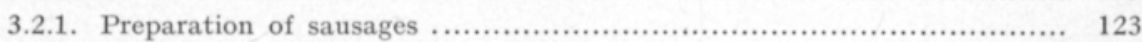

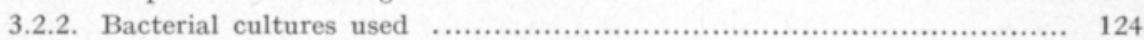

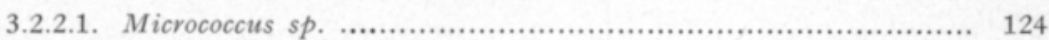

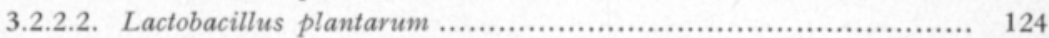

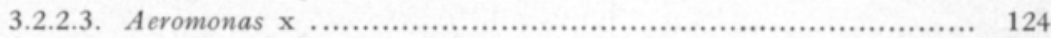

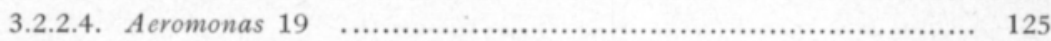

3.2.2.5. Vibrio costicolus ............................................... 126

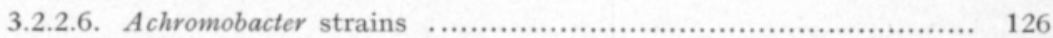

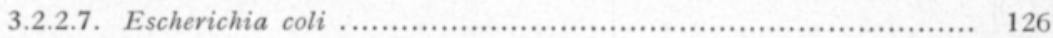

3.2.2.8. Proteus vulgaris ............................................... 126

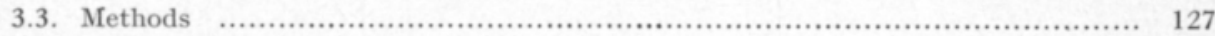

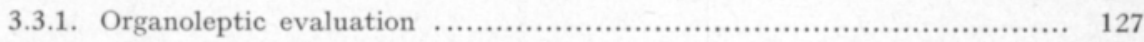

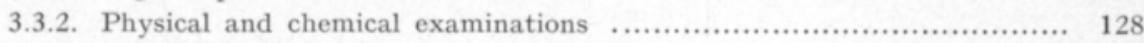

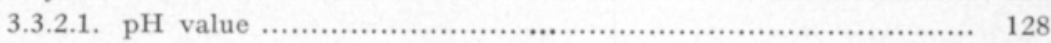

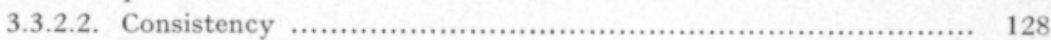

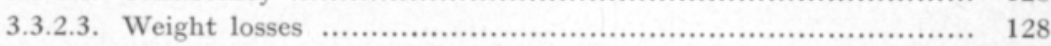

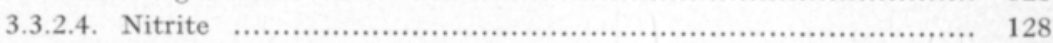

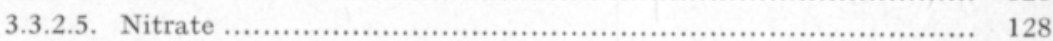

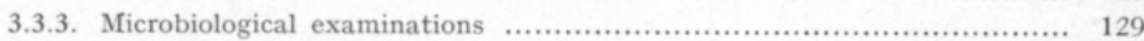

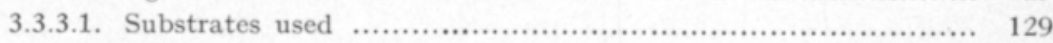

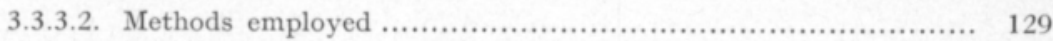

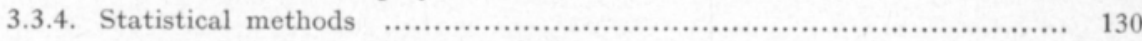

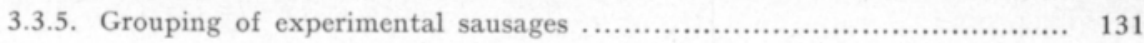




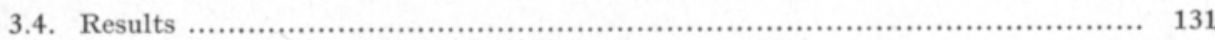

3.4.1. Use of Aeromonas strains as a starter culture ......................... 131

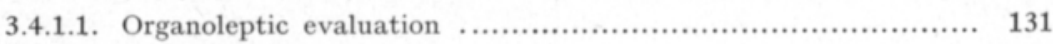

3.4.1.2. Physical and chemical examinations .............................. 138

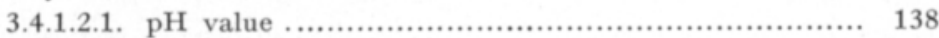

3.4.1.2.2. Consistency ............................................. 140

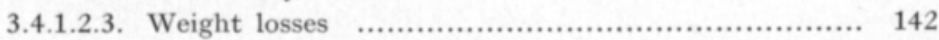

3.4.1.2.4. Nitrite .................................................... 143

3.4.1.2.5. Nitrate .................................................. 144

3.4.1.3. Microbiological examinations ..................................... 146

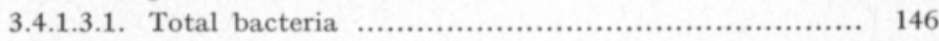

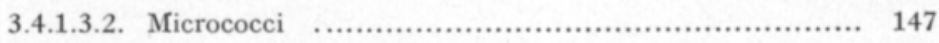

3.4.1.3.3. Total bacteria on tributyrine agar $\ldots \ldots \ldots \ldots \ldots \ldots \ldots . . \ldots . \ldots . \ldots 148$

3.4.1.3.4. Lipolytic bacteria .................................. 149

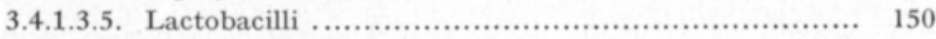

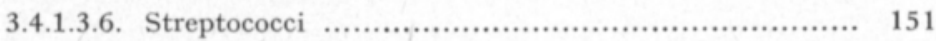

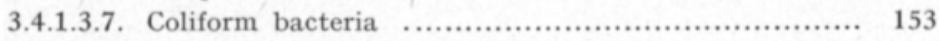

3.4.2. Use of Vibrio costicolus as a starter culture ............................. 154

3.4.3. Use of Achromobacter strains as a starter culture ....................... 154

3.4.4. Use of Escherichia coli as a starter culture ............................... 155

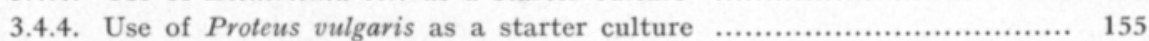

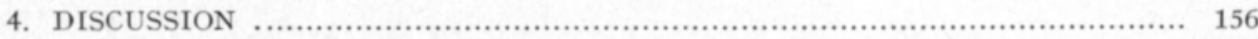

4.1. Effect of bacterial inoculations on the ripening of dry sausage ................ 156

4.2. Effect of bacterial inoculations on the bacterial flora of dry sausage ........... 158

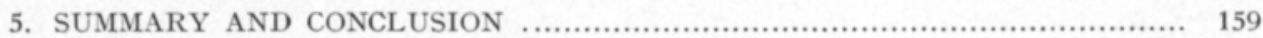

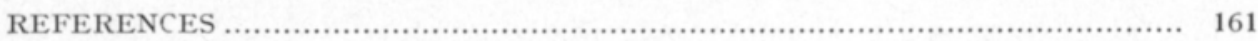

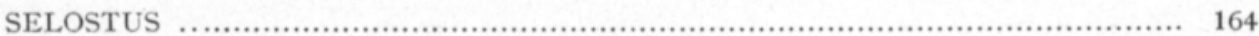




\title{
РетÄJÄ, E. 1977. The effect of some gram-negative bacteria on the ripening and quality of dry sausage. J. Scient. Agric. Soc. Finl. 49: 107-166.
}

\begin{abstract}
The possible use of gram-negative bacteria as starter cultures in dry sausage was studied by inoculating the following gram-negative bacteria into dry sausage both alone and with Lactobacillus plantarum: Aeromonas x, Aeromonas 19, Vibrio costicolus, Achromobacter 22, Achromobacter guttatus, Achromobacter X, Escherichia coli, or Proteus vulgaris. Sausage without any inoculation and sausage containing Micrococcussp. + Lactobacillus plantarum were used as references.

Aeromonas $\mathrm{x}$ and 19 strains had a very favourable effect on the quality of dry sausage when inoculated together with lactobacilli. Both strains reduced nitrate, and the colour formed during the first 3 days. The $\mathrm{pH}$ value of Aeromonas + Lactobacillus sausages decreased so quickly that the consistency of these sausages developed within one week and was at least as good as, and often firmer than in Micrococcus + Lactobacillus sausages. The consistency of Aeromonas $19+$ Lactobacillus sausages was better at the 0.05 significance level than that of Micrococcus + Lactobacillus samples. The aroma and flavour of Aeromonas + Lactobacillus sausages were as good as or better than those of Micrococcus + Lactobacillus sausages. The aroma and flavour of Aeromonas $19+$ Lactobacillus sausages were significantly better (significance level 0.001 ) than Micrococcus + Lactobacillus sausages. The flavour of Aeromonas $\mathrm{x}+$ Lactobacillus sausages was better at the 0.05 level than Micrococcus + Lactobacillus sausages.

The number of bacteria, roughly the number of lactobacilli, was often significantly higher in Aeromonas + Lactobacillus sausages (range $2-4 \times 10^{8} / \mathrm{g}$ between 3 and 21 days of ripening) than in Micrococcus + Lactobacillus sausages (range $8 \times 10^{7}-1.5 \times 10^{8} / \mathrm{g}$ between 3 and 21 days of ripening). For this reason the former sausages ripened more quickly than the latter.

Vibrio 21 and three Achromobacter strains did not thrive in dry sausage and disappeared during the first 7 days of ripening. When inoculated together with lactobacilli, Escherichia coli had almost as favourable an effect as micrococci on the quality of dry sausage. Inoculations of E. coli alone and Proteus vulgaris, both alone and with lactobacilli, did not improve the quality of dry sausage. $P$. vulgaris actually had a detrimental effect.

Conclusion

The investigation has proved that gram-negative bacterial strains Aeromonas $\mathrm{x}$ and 19 inoculated with lactobacilli improve the quality of dry sausage and that, especially with the Aeromonas $19+$ Lactobacillus inoculum, better dry sausage was obtained than with micrococci and lactobacilli.
\end{abstract}

\section{Introduction}

The manufacture of fermented food products, e.g. various dairy products, is based on the action of micro-organisms. The use of microbes ensures ripening and avoids the development of faulty products. The use of bacterial cultures 
in dairy products or different starting portions of ripe material in vegetable and bread products has been known for quite a long time. On the other hand, starter cultures in meat products have only been used during the last three decades.

Bacteria used as starter culture for dry sausage have been solely grampositive, generally lactic acid bacteria and micrococci. Mixing lactic acid bacteria with micrococci has proved beneficial for dry sausage. In cured meat products gram-negative bacteria have also been important. The traditional method has been to add old brine to new brine - to transfer bacterial inoculum to the new brine. Gram-negative bacteria often prevail in curing brines. They have also been inoculated artificially into the brines because they improve the colour formation and flavour of cured products. Some investigations into the effects of gram-negative bacteria on the quality of dry sausage have been made, but in practice gram-negative bacteria have not been used as starter culture for dry sausage. Most previous studies date from the 1950's and are not quite applicable to modern processing techniques, because shorter ripening times are used nowadays.

Because gram-negative bacteria can have a beneficial influence on meat curing and because their use in the manufacture of dry sausage has been little studied, the effect of some gram-negative bacteria on the ripening and quality of dry sausage will be clarified in this investigation. Attention will primarily be directed to the question of whether or not gram-negative bacteria can be used as starter culture for dry sausage.

\section{Review of the literature}

\section{1. Natural bacterial flora of dry sausage}

According to Coretti (1956 a, 1956 b) dry sausage contains mixed bacterial flora; the number of bacteria as ripening begins is about $4 \times 10^{6} / \mathrm{g}$. Mölle (1955) investigated the bacterial flora of the dry sausage masses from different factories and observed gram-negative bacteria dominating the flora. The number of bacteria increased according to CoRETTI (1956 a, $1956 \mathrm{~b}$ ) from $4 \times 10^{6} / \mathrm{g}$ to $3 \times 10^{8} / \mathrm{g}$ over 2 weeks. The number of enterococci varied from $1.6 \times 10^{4} / \mathrm{g}$ to $5 \times 10^{5} / \mathrm{g}$, the number of yeasts being $4 \times 10^{3}-3.1 \times 10^{4} / \mathrm{g}$. According to the same investigation the number of lactobacilli was very small when ripening began while in the ripened product lactobacilli predominated. According to Szczepaniak and Pezacki (1974) cocci formed the dominant microbial flora in dry sausage and smoking resulted in the destruction of gram-negative rods and yeasts. The total microbial counts increased from one million/g to 6-33 million/g during ripening.

REUTER et al. (1968) observed that the number of bacteria increased from $10^{4}-10^{5} / \mathrm{g}$ to $10^{8} / \mathrm{g}$ during the first $2-3$ days of ripening. The increase in lactobacillus counts during that time was from $10^{2}-10^{4} / \mathrm{g}$ to $10^{8} / \mathrm{g}$. The number of bacteria belonging to the genera Leuconostoc and Pediococcus was $0-10^{2} / \mathrm{g}$ 
during the first 4 days, increasing later to a level of $10^{3}-10^{4} / \mathrm{g}$. The sausage mass before stuffing contained $10^{4}-10^{5}$ enterobacter cells per gram, the count after $2-3$ days being $10^{2}$ or less per gram. The prevailing level of streptococcus and bacillus cells was $10^{4}-10^{5} / \mathrm{g}$ throughout ripening.

LERCHE (1956 a, 1956 b) found that the lactobacillus count at the beginning of ripening was low but increased considerably over $4-5$ days. During drying almost all gram-negative and a great part of the gram-positive bacteria disappeared and the ready product contained almost exclusively lactobacilli, micrococci and yeasts. FISZER (1970) stated that during the first 10 days of ripening the heterofermentative lactobacillus strains prevailed in dry sausage and thereafter the homofermentative strains dominated. However URBANIAK and PEZACKI (1975) proposed that the situation is just the opposite - that the homofermentative strains predominate at the beginning with heterofermentative strains being found increasingly later on. They also stated that the number of gram-negative bacteria decreased during ripening.

NinnivaAra and PoHJA $(1956,1957 \mathrm{a}, 1957 \mathrm{~b})$ found that during the beginning of the ripening of dry sausage the number of bacteria increased abundantly, micrococci forming the majority. The number of lactobacilli was also considerable but the count of gram-negative bacteria decreased, especially after smoking. The final flora were chiefly composed of lactobacilli.

TEN CATE (1960) observed that gram-negative bacteria disappeared from dry sausage as early as the first 2 or 3 days of ripening. Lactobacilli and Lancefield D group streptococci remained in the sausage. Also, according to ERIKSON (1961) gram-negative bacteria generally disappears completely and the micrococcus count decreases while Leuconostoc strains form the majority of bacterial flora. CoRETTI (1958) found Leuconostoc species in faulty dry sausages.

КАзвонм (1954) studied salami and cervelat sausages and found that the good products contained the most bacteria, especially lactobacilli. There was also an abundance of lactostreptococci, micrococci and yeasts. The sausages contained small but constant amounts of bacteria belonging to the mesentericussubtilis group, and gram-negative bacteria.

\section{2. Use of gram-positive bacteria and moulds in dry sausage}

\section{2. 1. MICROCOCCI}

It has been shown in many investigations that micrococci play an essential part in the ripening of dry sausage. When studying the bacterial flora of dry sausage, LERche $(1956 \mathrm{~b}, 1957)$ found about 50 bacterial species, with micrococci forming an essential part of the microbial flora. He also stated that smoking reduced the number of micrococci in dry sausage and that micrococci improved the colour of dry sausage depending on their ability to reduce nitrate.

NirnivaARA (1955) carried out extensive investigations into the influence of Micrococcus strains on the ripening process of dry sausage. A great number of Micrococcus strains were isolated in his work. A strain denoted $\mathrm{M}_{53}$ proved to be the best as to its starter culture properties. It accelerated the drop in the 
$\mathrm{pH}$ value so that in sausages inoculated with micrococci, a $\mathrm{pH}$ value of 5.4 was achieved in 2 days while in control sausages 5 days were needed for this. According to Niinivaara the development of colour depends on the reduction of nitrate and nitrite and on the $\mathrm{pH}$ value. The development of normal colour took 5 days in the control sausages but only 2 days in the sausages inoculated with micrococci. Further, Niinivaara observed that the control sausages were sometimes spoiled because of the influence of other bacteria. The Micrococcus strain $\mathrm{M}_{53}$ was found to have an antagonistic effect on the growth of other bacteria. Inoculation ensured the successful ripening of dry sausage and it was also possible to reduce the ripening time from 14 days for control sausages to 9 days for sausages containing micrococci. The acceleration and assurance of ripening are based on the following properties of Micrococcus $\mathrm{M}_{53}$ : its ability to reduce nitrate and to reduce the $\mathrm{pH}$ value of sausage, and its antagonism towards other microbes.

NinnvaARA and РонJA (1956) further clarified the role of micrococci in the preparation of dry sausage. According to them the micrococcus count increased more than that of other bacteria during the predrying of dry sausage. They also found, like LERCHE (1956 b), that smoking reduced the number of bacteria in dry sausage. In their later investigations (NIINIVAara 1958, NinnivaARA and Pohja 1957 a, 1957 b, 1957 c, PohJA and NinivaAra 1957) they stated that the Micrococcus strain $\mathrm{M}_{53}$ had an antagonistic effect upon most of the bacteria isolated from dry sausage, but not, however, upcn the Lactobacillus strains identified as Lactobacillus plantarum and Lactobacillus leichmannii.

In 1957 the Micrococcus strain $\mathrm{M}_{53}$ began to be used in the meat industry in the form of a preparation called "Baktoferment" (manufactured by Rudolf Müller \& Co., Giessen, FRG). This strain, isolated originally by Niinivaara, lost its activity fairly quickly and the strains used at present were isolated later. It is important, therefore, that new active strains be continually sought. Рон JA (1960) has presented a method for the selection of new strains suitable for manufacturing dry sausage.

KUCHLING (1963) found that nitrate-reducing micrococci promoted the development of a red colour but only during the first day after preparation. He further showed that micrococci have no effect on the aroma of the sausage but that they may disturb acid formation and so bring about faulty products. Kucharkova et al. (1963) found a Micrococcus aquatis strain which improves the quality of dry sausage. In Bulgaria a Micrococcus strain called $\mathrm{P}_{4}$ has been used in the manufacture of dry sausage (DJEvizov 1973, DJEDJEva 1973). It improves the quality of sausage and shortens the processing time.

\section{2. 2. LACTIC ACID BACTERIA}

JENSEN and PADDOCK (1940) were the first to clarify the possible use of lactobacilli in the preparation of semi-dry sausage. The strains used were Lactobacillus plantarum, Lactobacillus brevis and Lactobacillus leichmannii. They used both pure and mixed cultures and stated that lactobacilli reduced the ripening time, prevented the development of faulty products and improved the aroma of sausages. 
Niven et al. $(1955,1958)$ and Deibel et al. (1961 a, $1961 \mathrm{~b})$ extensively studied the possible use of lactic acid bacteria in semi-dry sausage - called summer sausage - in the USA. They found a Pediococcus cerevisiae strain which accelerated the ripening of semi-dry sausage and produced a firmer product with a strong, clean aroma. This strain does not reduce nitrate but forms lactic acid from glucose. Its optimum temperature is $+37^{\circ} \mathrm{C}$ and it is therefore applied in the manufacture of summer sausage, the internal temperature of which rises to $35-40^{\circ} \mathrm{C}$. The preparation takes some days. This strain has not been adopted for use in the manufacture of dry sausage in Europe.

The Pediococcus cerevisiae strain isolated by Niven and Deibel has been used commercially as a lyophilized preparation called "Acceln (manufactured by Merck \& Co., Rahway, N. J., USA). Merck \& Co. later developed a frozen pediococcus preparation (Lactacel) which is more active than the lyophilized one (EWERSon et al. 1970). More recently frozen cultures of Lactobacillus plantarum (Lactacel DS) and a mixture of L. plantarum and P. cerevisiae (Lactacel MC) have been made available (DEIBEL 1974).

The starter culture preparations Saga and Saga II (Manufactured by Microlife Technics, Sarasota, Fda, USA) contain lactic acid bacteria as a frozen suspension. Saga is for use in sausages fermented at smokehouse temperatures of $32-37^{\circ} \mathrm{C}$ and Saga II in sausages fermented at greenroom temperatures of $18-32^{\circ} \mathrm{C}$ (Sнан 1977). The cultures of lactic acid bacteria are also manufactured in France (LiePE 1975). According to CoRetti (1977) the French preparate called "Fermentes lactiques" contains lyophilized streptococci (Streptococcus lactis) in dried fat-free milk powder.

\section{2. 3. THE MIXTURE OF MICROCOCCI AND LACTIC ACID BACTERIA}

Niven (1952 a, 1952 b) found that both bacteria producing lactic acid and nitrate-reducing bacteria are required in the ripening of dry sausage. In spite of this, mixed starter cultures containing only homofermentative and heterofermentative lactobacilli were used in many plants in the USA (LEIsTNER 1963).

Nurmi $(1965,1966)$ developed a method in which both micrococci and lactobacilli were used in the preparation of dry sausage. According to Nurmi, lactobacilli used alone to inoculate sausage produced an essentially better consistency than micrococci. The consistency of control sausages was also much poorer. However, when the usual nitrate quantity was used, lactobacilli brought about discolourations and an off-flavour. This was caused by hydrogen peroxide formed by lactobacilli and oxidation of fat caused by hydrogen peroxide. The inoculation of just micrococci did not markedly accelerate the decrease in $\mathrm{pH}$ value and so the consistency developed no better than in the control sausages. The micrococci alone improved the colour of the cut surface of dry sausage a little.

When lactobacilli were inoculated along with micrococci into dry sausage, the bacteria were observed to considerably improve the quality of dry sausage. The lactobacillus inoculation markedly accelerated the ripening process while, 
on the other hand, micrococci prevented the discolourations caused by lactobacilli and reduced nitrate, thus promoting the formation of colour. According to Nurmi it is probable that the catalase formed by micrococci destroys hydrogen peroxide before it causes any harm. RozIER et al. (1970) also observed the catalase activity of micrococci necessary to assure the colour formation and stabilization by decomposing peroxides formed by lactic acid bacteria. Nurmi's experimental sausages inoculated with lactobacilli and micrococci ripened on average within $6-7$ days with a weight loss of about $10 \%$. The ripening time of control sausages was 19 days and respective weight loss $20 \%$. The lactobacillus inoculation required was given as $1-10$ million cells per gram. Nurmi used a micrococcus inoculation of 5-10 million cells per gram.

Nurmi concluded from his investigations that it is better to use lactobacilli and micrococci together as starter culture than either separately. He stated that lactobacilli considerably accelerate the decrease in $\mathrm{pH}$ and so promote the formation of a firm consistency. On the other hand micrococci promote colour formation and prevent discolouration and bad flavour which might be caused by inoculating only lactobacilli into sausages. From Nurmi's investigations a starter culture called "Duploferment 66" has been developed containing frozen or lyophilized micrococci and lactobacilli (manufactured by Rudolf Müller \& Co., Giessen, FRG).

The starter culture Saga III (manufactured by Microlife Technics, Sarasota, Fda, USA) also contains frozen micrococci and lactic acid bacteria and is used for dry sausages fermented at $10-32^{\circ} \mathrm{C}$ (SHAH 1977). Some mixed culture preparations are also on the market in Spain. According to CoRETTI (1977), these preparations called "Lamirlac" are mixtures of lyophilized lactobacilli, pediococci and micrococci and are prepared for different dry sausages, and dried and cooked hams.

InAL (1969) investigated the effect of Micrococcus aurantiacus and Pediococcus cerevisiae inoculated together on the ripening and quality of dry sausage. This starter culture combination ensured ripening and improved the colour, consistency and aroma of the sausages.

Sutic and Joksimovic (1973) inoculated dry sausage separately with Micrococcus strain M-104 and Streptococcus strain Ak-60 and with both strains together. The best quality, especially taste and aroma, was achieved with a culture containing both streptococci and micrococci. There were only small differences between other experimental sausage types. The $\mathrm{pH}$ value of the sausages did not decrease during ripening.

REUTER $(1970,1972)$ has studied the lactic acid bacteria of dry sausage. In addition to finding normal lactobacilli he found lactic acid bacteria which he called atypical streptobacilli. These bacteria were coccoid, grew at a lower temperature than normal lactobacilli and needed less oxygen than typical lactobacilli. REUTER (1972) also inoculated some atypical streptobacilli together with micrococci into dry sausage and observed that some strains had an unfavourable effect and some improved the quality, especially the flavour. Some strains even predominated in dry sausage over typical lactobacilli. 


\section{2. 4. BACILLI}

In the 1950's the role of bacilli was also studied. SсHÖNBERG (1953), SснӧNBERG and WALZ (1954), Baldenius (1954) and WALZ (1958) found that bacteria belonging to the genus Bacillus caused colour and flavour defects in dry sausage. CoRETTI (1958) inoculated Bacillus subtilis pure culture into dry sausage without any adverse effect on the products. In his opinion lactobacilli were the main reason for faulty products. PoHJA and NinnivaARA (1960) came to the conclusion that bacilli do not bring about any kind of change in dry sausage.

\section{2. 5. MOULDS}

Many countries manufacture dry sausage with mould flora on the surface. Most natural moulds are toxic and so not suitable for foodstuffs. Mintzlaff and Leistner (1972), however, have isolated a mould, Penicillium nalgiovensis, which is not toxic and has the right properties for use as a starter culture for dry sausage. The name of the commercial product developed from it is Edelschimmel Kulmbach 72 (manufactured by Rudolf Müller \& Co. Giessen, FRG).

\section{3. Gram-negative bacteria and their use in fermented meat products}

\section{3. 1. TAXONOMY}

Bergey's Manual (1974) classifies gram-negative bacteria according to cell shape, oxygen demands and metabolic character in the following way:

- aerobic rods and cocci

- facultatively anaerobic rods

- anaerobic bacteria

- cocci and coccobacilli

- anaerobic cocci

- chemolithotrophic bacteria.

Gram-negative aerobic rods and cocci includes the following families:

- Pseudomonadaceae

- Azotobacteraceae

- Rhizobiaceae

- Methylomonadaceae

- Halobacteriaceae.

This group also contains genera of uncertain affiliation: Alcaligenes, Acetobacter, Brucella, Bordetella, Francisella and Thermus.

Gram-negative facultatively anaerobic rods includes two families: Enterobacteriaceae and Vibrionaceae. Enterobacteriaceae contains 12 genera, among them being Escherichia, Salmonella, Shigella, Serratia and Proteus. Vibrionaceae contains five genera: Vibrio, Aeromonas, Plesiomonas, Photobacterium and 
Lucibacterium. There are also genera of uncertain affiliation like Chromobacterium, Flavobacterium, Haemophilus, Pasteurella etc.

Gram-negative anaerobic bacteria includes the family Bacteroidaceae and genera of uncertain affiliation.

The Neisseraceae family and two associated genera belong to the gramnegative cocci and coccobacilli group. Gram-negative anaerobic cocci consists of the family Veillonellaceae. Gram-negative chemolithotrophic bacteria contains the Nitrobacteriaceae family of organisms which oxidize ammonia or nitrite. This group also contains organisms that metabolize sulphur and organisms that deposit iron or manganese oxides.

\section{3. 2. METABOLIC PROPERTIES}

Among gram-negative bacteria there are metabolically versatile organisms forming acid from carbohydrates, alcohols etc., and which are both lipolytic and proteolytic. Nearly all gram-negative bacterial genera contain the strains that form acids from sugars and other compounds (BERGEY's MANUAL 1974). According to CAselitz $(1965$, p. 31,125$)$ lipolytic strains are to be found among bacteria belonging to the genera Pseudomonas and Aeromonas. Of the family Enterobacteriaceae the genus Proteus contains the most lipolytic strains (EDWARds and EwIng 1972, p. 324-328). The genera Pseudomonas and Aeromonas contain many proteolytic strains (CASELITZ 1965, p. 22, 119, BergeY's Manual 1974). There are also proteolytic bacteria which belong to the Enterobacteriaceae family. According to EDWARDs and EwING (1972, p. 324-328) the genus Proteus in particular contains proteolytic strains.

The lipolytic, proteolytic and saccharolytic activities of gram-negative bacteria are factors important in the aroma and flavour when these bacteria are used as starter cultures in dry sausage (Keller 1954, Keller and Meyer 1954). According to Buttiaux (1959) aeromonads play an important part in the biological processes on which the manufacture of raw sausage is based. Many gram-negative bacterial strains such as pseudomonads, aeromonads and enterobacteria reduce nitrate to nitrite (BERgEY's Manual 1974). As is known the nitrate reduction is an important factor in the manufacture of dry sausage.

\section{3. 3. TOXINS AND PATHOGENICITY}

Most gram-negative bacteria possess endotoxins. Endotoxins are complex lipopolysaccharides derived from the walls of bacterial cells and often liberated when bacteria lyse. The physiopathogenic effects of all endotoxins are similar, although they appear to be distinct antigenically. The sequence of monosaccharide units imparts antigenic specificity to the molecule. The specific antibody combines with the polysaccharide portion of the molecule (JAWETZ et al. 1968, p. 294).

The different types of toxins of gram-negative bacteria are classified according to their antigenic nature as follows: somatic $(\mathrm{O})$, flagellar $(\mathrm{H})$ and capsular (K) antigens. The common antigen (CA) and a thermostable antigen of salmo- 
nellae are also known (EDWARDS and EWING 1972, p. 48, 54). MÄKELÄ and MEYER (1976) suggest that all bacteria belonging to the family Enterobacteriaceae have the common antigen (ECA) and that other gram-negative bacteria do not. The presence of this antigen can be a virulence factor.

It is known that there are many pathogenic organisms among gram-negative bacteria, especially bacteria belonging to facultatively anaerobic rods such as enterobacteria. Bacteria belonging to the genera Salmonella and Shigella of the Enterobacteriaceae family are the most pathogenic. However, some Escherichia coli and Proteus strains are also pathogenic. Some E. coli strains may even be very pathogenic and cause diarrhoeal inflammations and other infections (Bergey's Manual 1974).

Among pseudomonads Pseudomonas aeruginosa, and among vibrios Vibrio comma, are generally known to be pathogenic. Most Pseudomonas and Vibrio bacteria are, however, apathogenic and saprophytic. The genus Aeromonas includes bacteria which are pathogenic for fish, frogs and other water animals (CAselitz 1965, p. 57-59). According to Caselitz (1965, p. 59-60) A. hydrophila is also pathogenic for mice, guinea pigs, rats, pigeons, and rabbits. Caselitz also stated that pathogenic aeromonads are haemolytic. DAHLE and Nordstoga (1968) also found aeromonas bacteria pathogenic for mice and possibly for blue fox but not for mink or seals. CASELITZ (1965, p. 74-77) presents five cases in which Aeromonas hydrophila has been pathogenic for man. The diagnosis was septicaemia twice, diarrhoea twice and osteomyelitis once.

\section{3. 4. GRAM-NEGATIVE BACTERIA IN MEAT CURING}

Bacteria with a beneficial effect on meat curing may be both gram-positive and negative. In many countries a curing method in which old brine is mixed with new is used. The purpose of this method is to transfer bacteria to the brine to be made before the curing process. Leistner (1960) examined the effect of bacteria in brines made in the above way on the brine itself, and on the products cured in those brines. In his opinion micro-organisms may improve the colour or flavour of the ready products, and stabilize brines.

Leistner observed that micrococci and lactobacilli improve the stability of curing brines and prevent their spoilage. He is also of the opinion that bacteria belonging to the genera Vibrio, Spirillum, Achromobacter, Alcaligenes and Micrococcus improve colour formation by reducing nitrate or affecting the $\mathrm{pH}$ and redoxpotential values favourably.

Leistner observed the influence of bacteria on the flavour of cured products. At least micrococci improve the flavour. Also, the optimal mixed cultures have a beneficial effect on the flavour of cured meat products. One mixed culture which Leistner found beneficial contained bacteria belonging to the following genera: Micrococcus, Vibrio, Spirillum, Achromobacter, Alcaligenes, Lactobacillus, Microbacterium and Corynebacterium. The effect is stronger if the culture is inoculated both into the cover brine and the pumping brine.

Buttiaux (1957) isolated a nitrate-reducing Vibrio costicolus strain which was used in meat curing in France. It was of great importance because the use 
of nitrite was not allowed in France. In Germany $V$. costicolus was also found to have a beneficial effect on the flavour of cured products. In Great Britain Achromobacter strains have been used in brines to improve the quality of meat products (Hawthorn and LeITCH 1962, p. 281). These strains have been found to have the same biochemical properties as the Vibrio costicolus of Buttiaux.

PEtÄJÄ $(1972,1973)$ found Vibrio costicolus and Achromobacter strains which proved successful in meat curing, used both in cover brine and especially in the brine to be injected into meat. The strains were used as starter culture in dried hams. They had a favourable effect on the colour, consistency and flavour of hams. The respective control hams were raw after 7 days of ripening.

Gorbatov et al. (1974) used Achromobacter guttatus with Streptococcus lactis, Lactobacillus plantarum, Micrococcus caseolyticus and Micrococcus varians in the curing of canned "Vetchina hams" and found that this kind of mixed culture improves the flavour of hams.

\section{3. 5. GRAM-NEGATIVE BACTERIA IN THE PREPARATION OF DRY SAUSAGE}

The influence of gram-negative bacteria on the quality of dry sausage, especially on the aroma and flavour, was investigated in the 1950's. KoHNLE (1953) stated that some Achromobacter and Escherichia strains produce the characteristic aroma of dry sausage and that micrococci and lactobacilli do not produce any kind of aroma. Alcaligenes, Pseudomonas and Aerobacter species are also able to create characteristic aromas. Keller (1954) investigated the effect of bacterial strains isolated by Kohnle and belonging to the genera Alcaligenes, Pseudomonas, Achromobacter, Aerobacter and Escherichia on the aroma of dry sausage and found one Escherichia strain and two Achromobacter strains to have the best effect. Keller and Meyer (1954) inoculated dry sausages with 5 Escherichia, 2 Alcaligenes, 1 Pseudomonas and 2 Achromobacter strains and found one Escherichia strain to have an especially favourable effect on the flavour of dry sausage, this being caused by fat breakdown products. MEYER (1954) also investigated the effect of Kohnle's strains on the aroma of dry sausage. One Escherichia strain proved best. Losem (1956) also stated that this strain improves the flavour of dry sausage. He also isolated it from dry sausage after a ripening period of 9 weeks.

ECKert (1958) inoculated dry sausage with Micrococcus $\mathrm{M}_{53}$ (NinnivaARA 1955) together with an Escherichia strain and obtained sausages whose colour and aroma were especially good. Both strains disappeared from the sausage during the ripening period of 40 weeks.

The ripening time of the sausages recorded by the school of Keller was long compared with processing times nowadays. Also, the $\mathrm{pH}$ value of the sausages was high - over 6.0 - making it possible for gram-negative bacteria to grow and thrive in dry sausage.

NuRmi (1966) inoculated dry sausage with two nitrate-reducing strains, one being Escherichia coli and the other Aerobacter cloaceae according to BERGEY's MANUAL (1957). The strains were used together with Lactobacillus plan- 
tarum. Aerobacter + Lactobacillus sausages had a peculiar mild flavour characteristic of sausages inoculated with lactobacilli. When Escherichia coli was used with lactobacilli the peculiar flavour was not found. The colour of the sausages was essentially a lighter red than that of sausages inoculated with lactobacilli and micrococci.

\section{Experimental}

\section{1. Purpose of the study}

Gram-negative bacteria are known to be useful in curing brines and improve the aroma and flavour of the cured meat products. The purpose of this investigation is to establish whether or not it is possible to use gram-negative bacteria as a starter culture in dry sausage and to find new, improved strains to be used as a starter culture in dry sausage. This is done by inoculating dry sausage with the following bacteria both alone and with lactobacilli: Aeromonas $\mathrm{x}$, Aeromonas 19, Vibrio costicolus, three Achromobacter strains, Escherichia coli and Proteus vulgaris. The effect of inoculated bacteria on the ripening, quality and bacterial flora of dry sausage is examined.

\section{2. Material}

\section{2. 1. PREPARATION OF SAUSAGES}

Twenty-two series of experiments were used in the investigation. Each series contained 6 different sausage groups and a group of $6-7$ identical sausages. Sausages were prepared using the following formula:

\begin{tabular}{|c|c|}
\hline Beef & $33.4 \%$ \\
\hline Pork ….................................. & $33.4 \%$ \\
\hline 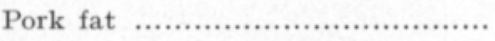 & $30.0 \%$ \\
\hline Seasoning salt mixture $\ldots \ldots \ldots \ldots \ldots$ & $3.2 \%$ \\
\hline
\end{tabular}

Seasoning salt mixture:

\begin{tabular}{|c|c|}
\hline Sodium chloride $. . . \ldots \ldots \ldots \ldots \ldots \ldots \ldots \ldots . \ldots . \ldots . \ldots$ & $89.7 \%$ \\
\hline 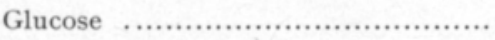 & $9.0 \%$ \\
\hline Potassium nitrate $. . . \ldots \ldots \ldots \ldots \ldots \ldots \ldots . . . . . . . .$. & $0.625 \%(200 \mathrm{ppm}$ in sausage) \\
\hline 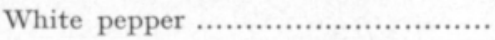 & $0.7 \%$ \\
\hline & $100.0 \%$ \\
\hline
\end{tabular}

One batch contained $34.2 \mathrm{~kg}$ of sausage mass; the raw materials were mixed and ground in a cutter of 2001 capacity (Seydelmann, manufactured by Maschinenfabrik Seydelmann, Stuttgart, FRG). The mixture was left quite rough and divided into 6 equal parts each containing $5.7 \mathrm{~kg}$. Each portion was inoculated and grinding was completed in a $40 \mathrm{l}$ cutter (Seydelmann, Rasant 
K-40, manufactured by Maschinenfabrik Seydelmann, Stuttgart, FRG). 100 $\mathrm{ml}$ of cell suspension was used for each $5.7 \mathrm{~kg}$. The control portion was prepared first and the cutter was cleaned after the preparation of each portion. The sausage mass was stuffed into a casing $60 \mathrm{~mm}$ in diameter (Visko PK $\mathrm{X}$, manufactured by $\mathrm{Oy}$ Visko Ab, Hanko, Finland), the weight of one sausage being about $0.5 \mathrm{~kg}$. The sausages were ripened as follows:

\begin{tabular}{ccc}
\hline ripening time & temperature & humidity \\
\hline $0-4$ days & $22^{\circ} \mathrm{C}$ & $95 \%$ \\
$4-7$ days & $21^{\circ} \mathrm{C}$ & $90 \%$ \\
$7-21$ days & $15-16^{\circ} \mathrm{C}$ & $80 \%$ \\
\hline
\end{tabular}

The ripening of the sausages was followed for 21 days. The samples inoculated with lactobacilli ripened in 10 days while sausages with other inoculations or without any inoculation sometimes did not ripen even in 21 days. After 14 days the sausages had ripened so that they could best be compared with each other.

\section{2. 2. BACTERIAL CULTURES USED}

\section{2.2.1. Micrococcus sp.}

The strain employed was isolated from the commercial product "Bactoferment 61. (manufactured by Rudolf Müller \& Co, Giessen, FRG). The cells were cultivated in the nutrient broth (see 3.3.3.1. h) by aeration, the incubation temperature being $30^{\circ} \mathrm{C}$. It took $1-2$ days to produce enough cells. The cells were separated centrifugally. The cell mass was covered with glucose, frozen and lyophilized (Lyophilizer Christ Delta 1/1 a, manufactured by Martin Christ, Osterode am Harz, FRG). The lyophilized cells were stored for 4 days before use. Lyophilized cells were suspended in $2 \%$ sodium chloride solution just before inoculation into the sausage mass. The inoculations varied between $10^{6}$ and $10^{7}$ cells/g of sausage mass.

\section{2. 2. 2. Lactobacillus plantarum}

The Lactobacillus strain used was L. plantarum (Nurmi 1966). It was isolated from the commercial product "Duploferment 66" (manufactured by Rudolf Müller \& Co, Giessen, FRG). The cells were cultivated in MRS broth (see 3. 3. 3. 1. i) by aeration, the incubation temperature being $30^{\circ} \mathrm{C}$ and the time one day. The cells were separated, covered with glucose, frozen, lyophilized and stored for 4 days before use, as with micrococci. Lyophilized cells were suspended in $2 \%$ sodium chloride solution before inoculation. The inoculations varied between $10^{6}-10^{7}$ cells/g of sausage mass.

\section{2.2.3. Aeromonas $x$}

Aeromonas $\mathrm{x}$ was isolated from dry sausage (control sausage of experimental series IV in this study). The cell preparates used as an inoculum were made in 
the same way as micrococci preparates. However the cultivation of one day was enough. The inoculations varied between $10^{6}$ and $10^{7}$ cells/g of sausage mass.

Some properties of Aeromonas x were investigated. According to the results, Aeromonas $\mathrm{x}$ is a gram-negative rod with polar flagella. Its properties are as follows:

- fermentative

- oxidase positive

- catalase positive

- lipolytic

- grows well in salt concentrations under $5 \%$ and at temperatures of $20-37^{\circ} \mathrm{C}$

- reduces nitrate

- liquefies gelatin

- forms acids from the following substrates: glucose, fructose, mannose, galactose, sucrose, maltose, xylose, raffinose, mannitol, sorbitol, glycerol and salicin.

- does not form acid from the following substrates: lactose, arabinose, rhamnose and esculin.

- not haemolytic

Aeromonas $\mathrm{x}$ has been classified as belonging to Aeromonas genus on the basis of Bergey's Manual (1974). In Bergey's Manual three species (A. hydrophila, A. punctata, A. salmonicida) and some subspecies are presented. The properties of Aeromonas $\mathrm{x}$ do not correspond to the properties of the three species and subspecies described.

Pat hogenicity

The examination was carried out by inoculating intraperitoneally different numbers of bacterial cells into white mice. As a result of the apathogenicity examination of Aeromonas $\mathrm{x}$, the $\mathrm{LD}_{50}$ value lies between $5 \times 10^{7}$ and $10^{8}$. It is known that gram-negative bacteria produce endotoxins and are so able to kill mice when inoculated in sufficient quantities.

According to MäKELÄ (1975) gram-negative bacteria having an $\mathrm{LD}_{50}$ value of $10^{8}$ or more are apathogenic. VALTONEN (1970) considered Salmonella typhimurium strains having a value of $10^{8}$ avirulent.

\section{2. 2. 4. Aeromonas 19}

Aeromonas 19 was isolated from dry sausage (control sausage of experimental series XVII in this research). The cell preparation was made and inoculated in the same way as that of Aeromonas x. The inoculations varied between $10^{6}$ and $10^{7}$ cells/g of sausage mass.

Aeromonas 19 is a gram-negative rod with polar flagella. Its properties are as follows:

- fermentative

- oxidase positive

- catalase positive 
- lipolytic

- grows well in salt concentrations under $5 \%$ and at the temperatures of $20-37^{\circ} \mathrm{C}$

- reduces nitrate

- liquefies gelatin

- forms acids from the following substrates: glucose, fructose, mannose, galactose, sucrose, maltose, xylose, mannitol, sorbitol, glycerol and salicin.

- does not form acid from the following substrates: lactose, raffinose, rhamnose and esculin. Acid was formed only weakly from arabinose.

- not haemolytic

Aeromonas 19 has also been identified according to Bergey's Manual (1974) and does not correspond exactly with three species or subspecies presented, either.

\section{P a thogen ic it y}

The $\mathrm{LD}_{50}$ value of Aeromonas 19 was observed to be about $10^{8}$. So according to what has just been said (chapter 3.2.2.3.) it can be regarded as apathogenic.

\section{2. 2.5. Vibrio costicolus}

The Vibrio costicolus strain used had been isolated from curing brine (PETÄJ $\ddot{A}$ et al. 1973). A lyophilized $V$. costicolus preparation was made and inoculated in the same way as that of Aeromonas strains, the inoculum being $10^{6}-10^{7}$ cells/g of sausage mass.

\section{2. 2.6. Achromobacter strains}

Achromobacter 22 (Рет̈̈J from Nora Winterhalter of Eidgenossische Technische Hochschule, Zürich) and Achromobacter $X$ (isolated from control dry sausage, experimental series XIV) were used as starter cultures. The strains were classified according to Bergey's Manual (1957). The lyophilized preparations were made and inoculated in the same way as those of Aeromonas $\mathrm{x}$ and 19 , the inoculum being $10^{6}-10^{7}$ cells/g of sausage mass.

\section{2. 2.7. Escherichia coli}

The strain of Escherichia coli used was obtained from the Institute of Microbiology of the University of Helsinki. E. coli cells were inoculated as a lyophilized preparation made in the same way as Aeromonas preparations. The cells were suspended in $2 \%$ sodium chloride solution just before inoculation, the inoculum being $10^{6}-10^{7}$ cells/g of sausage mass.

\section{2. 2. 8. Proteus vulgaris}

The strain of Proteus inlgaris used originated from the Institute of Microbiology of the University of Helsink. P. vulgaris was inoculated as a lyo- 
philized preparation made in the same way as Aeromonas preparations. The cells were suspended in $2 \%$ sodium chloride solution just before inoculation, the inoculum being $10^{6}-10^{7}$ cells/g of sausage mass.

\section{3. Methods}

\section{3. 1. ORGANOLEPTIC EVALUATION}

The panel carrying out the evaluation consisted of five persons familiar with the organoleptic evaluation of dry sausage. Before evaluation, the quality desirable in experimental sausages was established. This was achieved by training evaluations. The experimental sausages were evaluated when they were $1,3,7,10,14$ and 21 days old. The following properties were evaluated: colour of sliced surface, consistency, aroma and flavour. The flavour of 1 and 3 day old sausages was not evaluated. A scoring system and a descriptive method were used side by side as the evaluation method. The choices offered to the panel members were as follows:

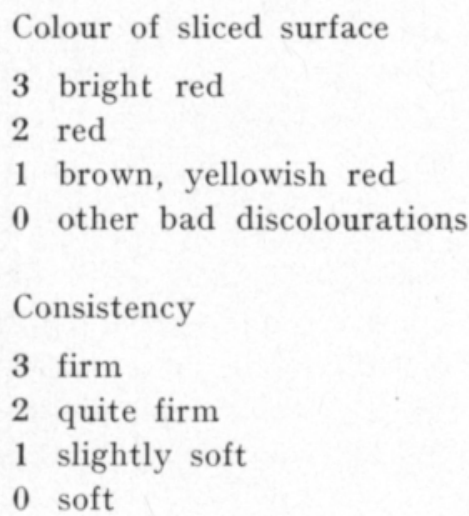

Aroma

3 excellent

$2 \operatorname{good}$

1 odourless

0 unpalatable
Flavour
3 excellent
2 good
1 moderate
0 bad

Because the panel members could also award half points the points were multiplied by 2 before statistical processing. 


\section{3. 2. PHYSICAL AND CHEMICAL EXAMINATIONS}

\section{3. 2.1. $p H$ value}

$\mathrm{pH}$ values were measured after $0,1,3,7,10,14$ and 21 days of ripening using a Findip digital $\mathrm{pH} \& \mathrm{mV}$ meter 555A (manufactured by Oy Findip $\mathrm{Ab}$, Kauniainen, Finland).

\section{3. 2. 2. Consistency}

Consistency was measured using an Instron instrument MO821 TM-M (manufactured by Instron Limited, High Wycombe, Bucks, England). A $7 \mathrm{~cm}$ long piece of sausage was used in the measurements. The sausage was compressed $1 \mathrm{~cm}$ with the measuring device which was $5.6 \mathrm{~cm}$ in diameter and the instrument registered the force needed. Measurements were made in three positions and their mean value was calculated. The results were expressed in kilograms. Consistency was measured after 1, 3, 7, 10, 14 and 21 days of ripening at room temperature.

\section{3. 2. 3. Weight losses}

Weight losses were determined by weighing the sample sausages to be studied before other determinations. This means that figures for weight losses were obtained after ripening times of $1,3,7,10,14$ and 21 days.

\section{3. 2. 4. Nitrite}

The quantity of nitrite was determined according to the method of STOYA (1969). The protein was precipitated using di-sodium tetraborate-10-hydrate and zinc sulphate-7-hydrate. In this study the precipitate was separated centrifugally instead of by filtration. Nitrite was determined from the liquid phase using sulfanilic acid and $\alpha$-naphthole. The determination was carried out after $0,1,3,7,10,14$ and 21 days of ripening.

\section{3.2.5. Nitrate}

The nitrate quantity was also determined by the method of STOYA (1969). The protein precipitation took place in the same way as in the nitrite determination. In the liquid phase the nitrate was reduced to nitrite by cadmium released by reducing cadmium sulphate with zinc powder. The total nitrite content was determined using the sulfanilic acid and $\alpha$-naphthole reagents. The nitrate content was calculated using nitrite and nitrate standards determined in conjunction with the analyses. The nitrate was determined after 1, 3, 7, 10, 14 and 21 days of ripening. 


\section{3. 3. MICROBIOLOGICAL EXAMINATIONS}

\section{3. 3.1. Substrates used}

a) Plate count agar for counting total number of bacteria, Merck No. 5463. Manufactured by Merck, Darmstadt, FRG.

b) Mannitol salt agar for counting staphylococci and micrococci. Manufactured by Orion Oy, Helsinki, Finland.

c) Tributyrine agar for counting lipolytic bacteria. Manufactured by Orion Oy, Helsinki, Finland.

d) Rogosa agar for counting lactobacilli (Rogosa et al. 1951). Manufactured by Orion Oy, Helsinki, Finland.

e) Slanetz agar for counting enterococci and streptococci of the Viridans group (Slanetz and Bartley 1957). Manufactured by Orion Oy, Helsinki, Finland.

f) VRB (violet red bile) agar for counting coliform bacteria. Manufactured by Orion $\mathrm{Oy}$, Helsinki, Finland.

g) Hugh-Leifson semi-solid agar for fermentation and oxidation examinations in identification tests (HUGH and LeIfSON 1953).

h) Nutrient broth according to PETÄJÄ (1977) for mass cultivation of different bacteria (developed for Vibrio costicolus at the Institute of Meat Technology of the University of Helsinki).

i) MRS broth for mass cultivation of lactobacilli (de MaN et al. 1960).

\subsubsection{Methods employed}

Experimental sausages were studied microbiologically after 0, 1, 3, 7, 10, 14 and 21 days of ripening. Dilution 1 was made in the following way: 10 grams of sausage was weighed into $90 \mathrm{ml}$ of $2 \%$ sodium chloride solution with a sterile spoon. The mixture was homogenized using an Ultra Turrax homogenizer TP 18/2 (manufactured by Janke \& Kunkel KG, Staufen i. Br., FRG). The other necessary dilutions were also made in $2 \%$ sodium chloride solution. If possible the count of bacteria was made by using plates on which the number of colonies varied between 30 and 300 .

The following examinations were made:

a) Cultivation on plate count agar, plating method.

Incubation for 4 days at $30^{\circ} \mathrm{C}$.

The total number of bacteria was determined on plate count agar. All the colonies were recorded.

b) Cultivation on mannitol salt agar, spreader method.

Incubation for 2 days at $37^{\circ} \mathrm{C}$.

Round and entire colonies were recorded, the count including both micrococci and staphylococci.

c) Cultivation on tributyrine agar, spreader method.

Incubation for 4 days at $30^{\circ} \mathrm{C}$. 
The lipolytic bacteria, of which inoculated Aeromonas strains separately, were determined on tributyrine agar by counting the colonies having a distinct lipolysis halo. The total number of bacteria was also counted.

d) Cultivation on Rogosa agar, plating method.

Incubation for 4 days at $30^{\circ} \mathrm{C}$.

The number of lactobacilli was determined on Rogosa agar. All the colonies were recorded.

e) Cultivation on Slanetz agar, spreader method.

Incubation for two days at $37^{\circ} \mathrm{C}$.

On Slanetz agar all red and reddish entire colonies were counted, the results thus including enterococci and streptococci of the Viridans group.

f) Cultivation on VRB agar, plating method.

Incubation one day at $37^{\circ} \mathrm{C}$.

Coliform bacteria form deep red colonies on VRB agar $1-2 \mathrm{~mm}$ in diameter. Only these kinds of colonies were recorded.

g) Identification of Aeromonas strains.

Some strains that grew well in good quality dry sausage were identified. The first studies consisted of the following examinations: gram staining and microscopic examination, growing experiments at temperatures of $20-37^{\circ} \mathrm{C}$ and in $\mathrm{NaCl}$ concentrations of $0-5 \%$, reduction of nitrate, catalase and oxidase tests and further proteolytic, lipolytic and starch hydrolytic properties. Later the oxidation and fermentation tests and acid formation from the following substrates were investigated: glucose, fructose, mannose, galactose, sucrose, maltose, lactose, xylose, arabinose, raffinose, rhamnose, mannitol, sorbitol, glycerol, salicin and esculin.

h) Determination of pathogenicity of Aeromonas strains.

The apathogenicity of Aeromonas strains was examined by inoculating intraperitoneally different numbers of bacterial cells into white mice. These studies were carried out in the State Veterinary Medical Institute, Helsinki.

\section{3. 4. STATISTICAL METHODS}

The results of the organoleptic evaluation were tested by analysis of variance both without separating the samples of different ages and also by handling sausages of different ages separately. The comparison of different sausage group pairs was carried out using the t-test. The different properties were treated separately. The following notations were used to express the degree of significance:

$\begin{array}{lll}+++ \text { samples different, significance level } & <0.001 \\ ++ & & <0.01 \\ + & : & \end{array}$

The presence of any significant differences between evaluations of panel members was tested in order to criticize the organoleptic evaluation. The standard deviation of the mean was used in the calculation of all the results. 


\section{3. 5. GROUPING OF EXPERIMENTAL SAUSAGES}

There were altogether twenty-two experimental sausage series. The composition of these series varied so that in different sequences the effect of different bacteria was studied. The sequences of investigation can be recorded in the following way according to the experimental series:

\begin{tabular}{cc}
\hline Experimental series & $\begin{array}{c}\text { Inoculated gram-negative } \\
\text { bacteria }\end{array}$ \\
\hline
\end{tabular}

\begin{tabular}{|c|c|}
\hline $1-6$ & $\begin{array}{l}\text { Vibrio } 21 \text { and different } \\
\text { Achromobacter strains }\end{array}$ \\
\hline $4-13$ & $\begin{array}{l}\text { Aeromonas } \mathrm{x}, \text { Escherichia coli and } \\
\text { Proteus vulgaris }\end{array}$ \\
\hline $14-16$ & Achromobacter $X$ \\
\hline $17-22$ & Aeromonas 19 \\
\hline
\end{tabular}

This work deals mainly with the effect of Aeromonas $\mathrm{x}$ and Aeromonas 19 on the quality of dry sausage. This is done by comparing their properties with those of control and Micrococcus + Lactobacillus sausages. The following schema will be used in describing the results:

1. Control group

2. Micrococcus + Lactobacillus group

3. Aeromonas $\mathrm{x}$ group

4. Aeromonas $\mathrm{x}+$ Lactobacillus group

5. Aeromonas 19 group

6. Aeromonas $19+$ Lactobacillus group

A short account will be given of the effect of other inoculated gram-negative bacteria on the ripening of dry sausage.

\section{4. Results}

\subsection{USE OF AEROMONAS STRAINS AS A STARTER CULTURE}

\section{4.1.1. Organoleptic evaluation}

Colour of sliced sausage

Fig. 1 and Table 1 show the differences in the mean scores of the sausages after different ripening periods. The sausage groups containing Lactobacillus inoculations are the best, the differences between them being very small. The colour of Micrococcus + Lactobacillus sausages is slightly better than that of Aeromonas x + Lactobacillus aud Aeromonas $19+$ Lactobacillus samples after 14 days of ripening. The colour develops at about the same rate in all three groups. 
Table 1. Effect of bacterial inoculations on colour of sliced surface of experimental sausages (scores $0-6)$.

\begin{tabular}{|c|c|c|c|c|c|}
\hline & Sausage group & 3 days & 7 days & 14 days & 21 days \\
\hline \multirow{4}{*}{1.} & Control & & & & \\
\hline & number of samples . .................... & 21 & 21 & 20 & 19 \\
\hline & 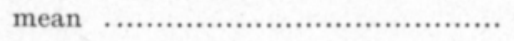 & 1.2 & 2.9 & 3.2 & 3.2 \\
\hline & s.d.m. ....................................... & 0.9 & 1.4 & 1.5 & 1.7 \\
\hline \multirow[t]{4}{*}{2.} & Micrococcus + Lactobacillus & & & & \\
\hline & number of samples ...................... & 15 & 15 & 15 & 13 \\
\hline & 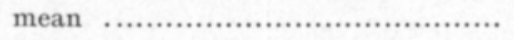 & 2.9 & 4.1 & 4.9 & 4.6 \\
\hline & 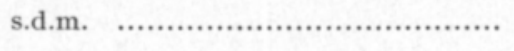 & 1.1 & 1.0 & 0.9 & 0.9 \\
\hline \multirow{4}{*}{3.} & Aeromonas $\mathrm{x}$ & & & & \\
\hline & number of samples ....................... & 5 & 5 & 5 & 5 \\
\hline & 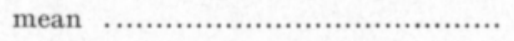 & 1.3 & 2.6 & 3.1 & 4.0 \\
\hline & 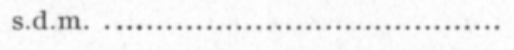 & 1.3 & 1.8 & 1.3 & 1.4 \\
\hline \multirow{4}{*}{4.} & Aeromonas $\mathrm{x}+$ Lactobacillus & & & & \\
\hline & number of samples ..................... & 6 & 6 & 6 & 6 \\
\hline & 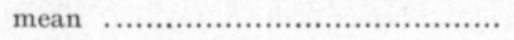 & 2.6 & 4.3 & 4.2 & 4.4 \\
\hline & 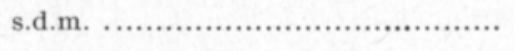 & 1.2 & 1.1 & 0.9 & 0.9 \\
\hline \multirow{4}{*}{5.} & Aeromonas 19 & & & & \\
\hline & number of samples $\ldots \ldots \ldots \ldots \ldots \ldots \ldots \ldots$ & 3 & 4 & 4 & 3 \\
\hline & mean & 2.7 & 3.0 & 3.9 & 3.6 \\
\hline & s.d.m. .................................... & 0.1 & 1.7 & 1.6 & 1.6 \\
\hline \multirow{4}{*}{6.} & Aeromonas $19+$ Lactobacillus & & & & \\
\hline & number of samples..$\ldots \ldots \ldots \ldots \ldots \ldots \ldots$ & 6 & 6 & 6 & 5 \\
\hline & 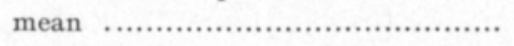 & 2.9 & 4.0 & 4.3 & 4.4 \\
\hline & s.d.m. ................................... & 1.0 & 1.0 & 1.2 & 1.0 \\
\hline
\end{tabular}

s.d.m. = standard deviation of mean

In the control and Aeromonas $\mathrm{x}$ sausages the colour was significantly worse than in other samples (Table 2), being brownish and developing slowly. The

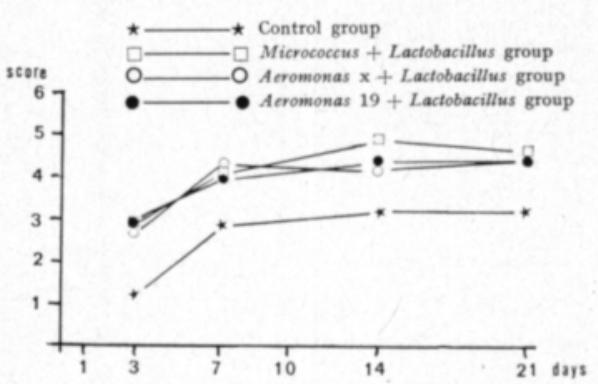

Figure 1. Effect of different bacterial inoculations on colour of sliced surface of sausage. colour of Micrococcus + Lactobacillus, Aeromonas $\mathrm{x}+$ Lactobacillus and Aeromonas $19+$ Lactobacillus sausages proved significantly better (significance level 0.05 ) than that of other samples. There was, however, no significant difference between them. Aeromonas 19 sausages were better than the control and Aeromonas $\mathbf{x}$ samples (Table 2). 
Table 2. Comparison of colour of sausage pairs using the t-test. Scores for sausages of different ages are not separated.

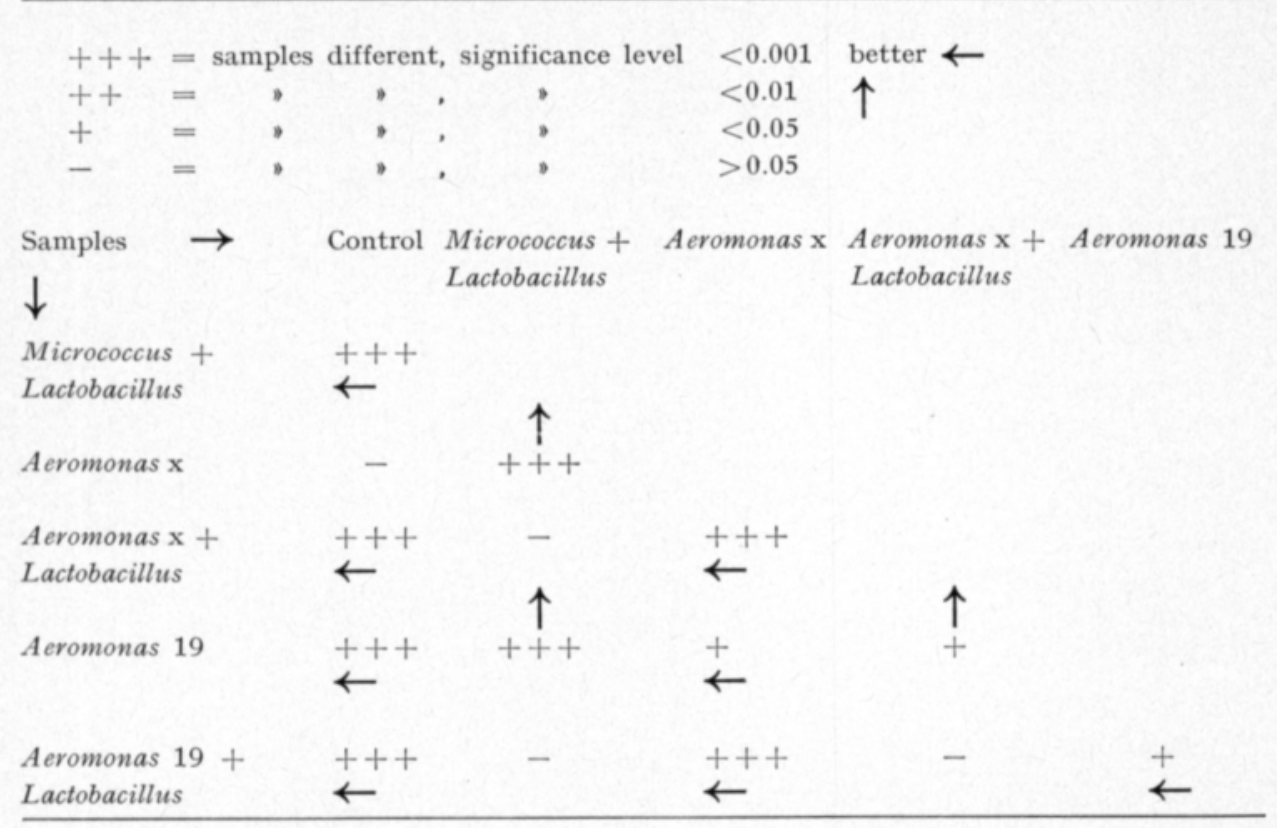

Cons isten c y

The mean consistencies of sausages of different ages are shown in Fig. 2 and Table 3. Aeromonas $19+$ Lactobacillus sausages are generally the best with Micrococcus + Lactobacillus samples the next best followed by Aero-

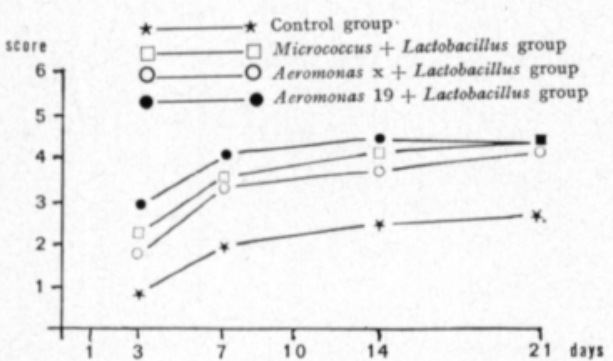

Figure 2. Effect of different bacterial inoculations on consistency of sausage. monas $\mathrm{x}+$ Lactobacillus sausages. This was also the order after 14 days of ripening. Taken throughout ripening, Aeromonas 19 sausages were bet $^{t}$ er than the control and Aeromonas $\mathrm{x}$ sausages.

The consistency of the control and Aeromonas x sausages was significantly worse than that of other samples (Table 4). The samples made using Lactobacillus inoculation were best. Sausages inoculated with micrococci and lactobacilli were not significantly better than Aeromonas x + Lactobacillus samples. Instead Aeromonas $19+$ Lactobacillus and Micrococcus + Lactobacillus sausages differed at the 0.05 level, the former being the better. Aeromonas $19+$ Lactobacillus samples were better than Aeromonas $\mathrm{x}+$ Lactobacillus ones at the 0.001 level. Aeromonas 19 sausages were better than samples with Aeromonas x. 
Table 3. Effect of bacterial inoculations on consistency of experimental sausages (scores $0-6$ ).

\begin{tabular}{lllll}
\hline Sausage group & 3 days & 7 days & 14 days & 21 days
\end{tabular}

1. Control

number of samples.

$\begin{array}{cccc}21 & 21 & 20 & 19 \\ 0.9 & 1.9 & 2.5 & 2.7 \\ 1.0 & 1.2 & 1.5 & 1.2\end{array}$

s.d.m.

1.0

1.2

1.2

2. Micrococcus + Lactobacillus

number of samples ................... 15

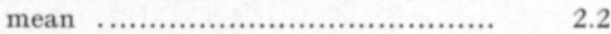

s.d.m. ......................................

15

15

13

3.5

4.2

4.5

3. Aeromonas $\mathrm{x}$

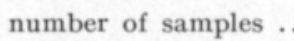

5

0.9

1.0

1.1

mean

0.6

5

5

5

s.d.m.

0.8

1.5

2.5

3.0

1.4

0.9

1.3

4. Aeromonas $\mathrm{x}+$ Lactobacillus number of samples ...................... 6

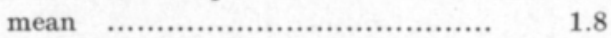

$6 \quad 6$

$6 \quad 6 \quad 6$

s.d.m.

5. Aeromonas 19

number of samples .......................

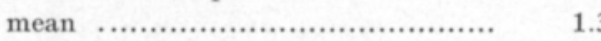

34

4

4

3

s.d.m.

1.2

2.5

3.2

3.5

1.3

1.1

1.5

6. Aeromonas $19+$ Lactobacillus number of samples .................... 6

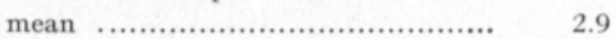

$\begin{array}{lll}6 & 6 & 5\end{array}$

s.d.m.

1.4

4.1

4.5

4.4

s.d.m. = standard deviation of mean

Table 4. Comparison of consistency of sausage pairs using the t-test. Scores for sausages of different ages are not separated.

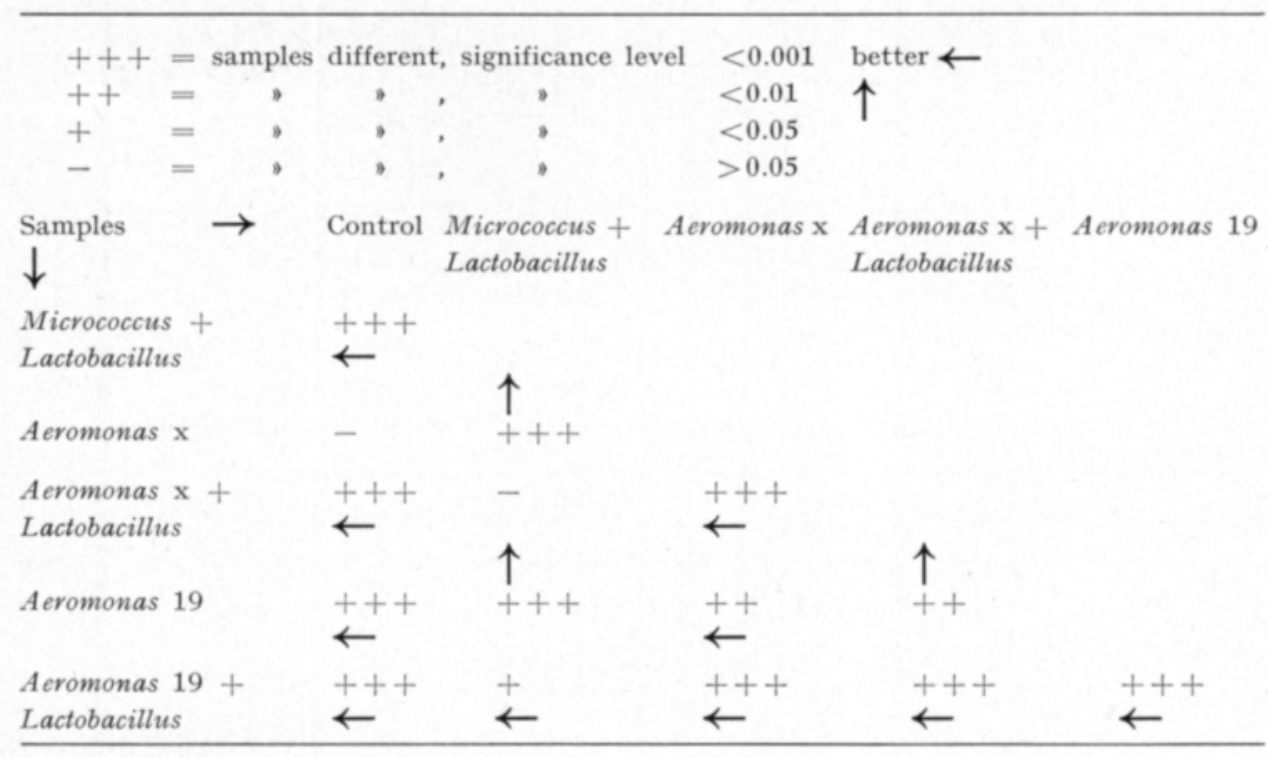


A rom a

The Aeromonas $19+$ Lactobacillus sausages were the best for most of the ripening time (Fig. 3 and Table 5). The order of preference of the Micrococcus + Lactobacillus, Aeromonas $\mathrm{x}+$ Lactobacillus and Aeromonas 19 sausages varied during ripening. The order of preference of sausages with Lactobacillus inoculation after 14 days of ripening was as follows: Aeromonas $19+$ Lactobacillus sausages were the best, second came Aeromonas $\mathrm{x}+$ Lactobacillus samples and third Micrococcus + Lactobacillus samples.

The aroma of the control and Aeromonas x sausages was significantly worse than that of other samples (Table 6). The Aeromonas 19 samples were clearly better than these, being statistically as good as Micrococcus + Lactobacillus and Aeromonas $\mathrm{x}+$ Lactobacillus samples, but worse than Aeromonas $19+$

Table 5. Effect of bacterial inoculations on aroma of experimental sausages (scores $0-6$ ).

\begin{tabular}{lllll}
\hline Sausage group & 3 days & 7 days & 14 days & 21 days
\end{tabular}

1. Control

number of samples.

s.d.m.

2. Micrococcus + Lactobacillus

number of samples

mean

s.d.m.

3. Aeromonas $\mathbf{x}$

number of samples

mean

s.d.m.

4. Aeromonas $\mathrm{x}+$ Lactobacillus

number of samples

mean

s.d.m.

5. Aeromonas 19

number of samples

mean

s.d.m.

6. Aeromonas $19+$ Lactobacillus

number of samples .................... 6

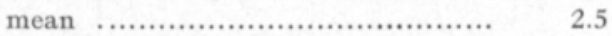

s.d.m. ................................... 0.8

s.d.m. = standard deviation of mean
21

1.4

21

2.4

1.3

15

3.0

1.0

15

3.6

13

1.9

0.9

\section{5}

1.1

1.0

6

1.6

1.2

3

2.2

1.4
5

2.2

1.4

5

$\begin{array}{lll}3.1 & 3.5 & 2.9 \\ 1.4 & 1.1 & 1.3\end{array}$

促 


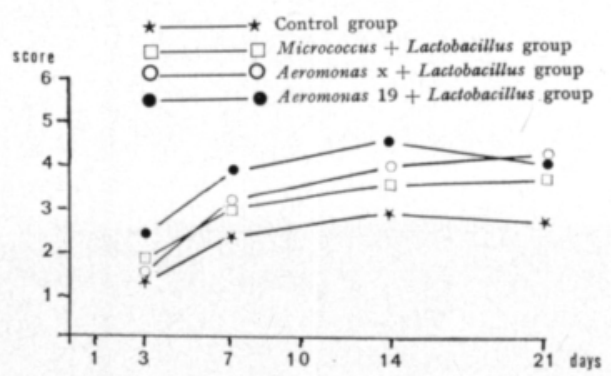

Figure 3. Effect of different bacterial inoculations on aroma of sausage.
Lactobacillus samples. There was no statistical difference between Micrococcus + Lactobacillus and Aeromonas $\mathrm{x}+$ Lactobacillus sausages, while Aeromonas $19+$ Lactobacillus samples were significantly better (significance level 0.001 ) than the other ones.

Table 6. Comparison of aroma of sausage pairs using the t-test. Scores for sausages of different ages are not separated.

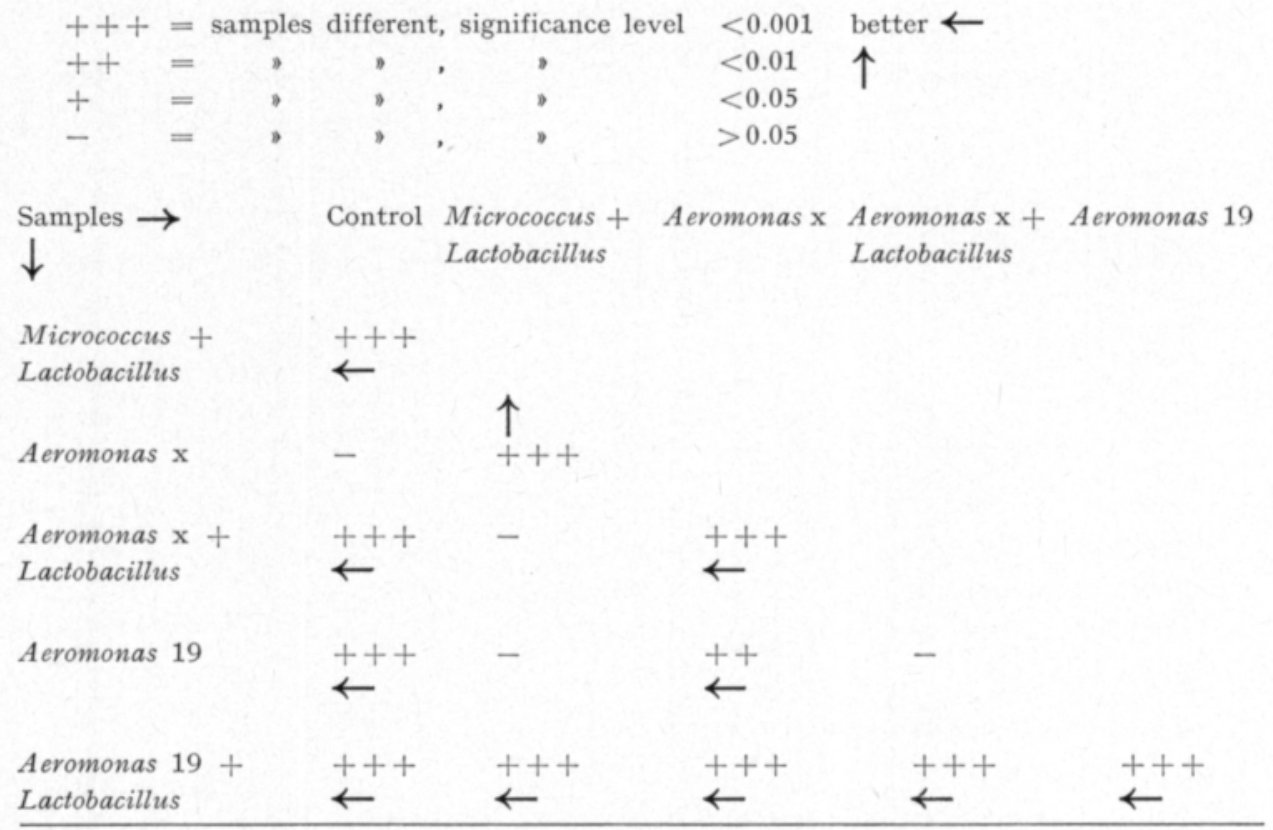

F 1 a vou r

The flavour of Aeromonas $19+$ Lactobacillus sausages was best after ripening times of 7 and 14 days (Fig. 4 and Table 7). Sausages with Aeromonas $\mathrm{x}$ + Lactobacillus and Micrococcus + Lactobacillus were next in this order throughout ripening. Aeromonas 19 sausages were better than both the control and Aeromonas $\mathrm{x}$ sausages throughout the ripening period.

The flavour of control and Aeromonas x sausages was the worst (Table 8). Aeromonas 19 samples were significantly better than these. However, the sausages inoculated with lactobacilli were best. Aeromonas $\mathrm{x}+$ Lactobacillus 
Table 7. Effect of bacterial inoculations on flavour of experimental sausages (scores $0-6$ ).

\begin{tabular}{llll}
\hline Sausage group & 7 days & 14 days & 21 days
\end{tabular}

1. Control

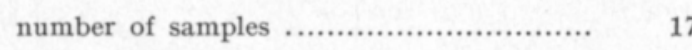

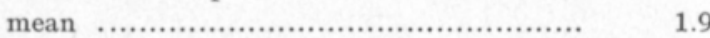

s.d.m.

2. Micrococcus + Lactobacillus

number of samples

mean

s.d.m.

3. Aeromonas $\mathrm{x}$

number of samples

mean

s.d.m.

4. Aeromonas $\mathrm{x}+$ Lactobacillus

number of samples

mean

s.d.m.

5. Aeromonas 19

number of samples

mean

s.d.m.

6. Aeromonas $19+$ Lactobacillus

number of samples

mean

s.d.m.

s.d.m. = standard deviation of mean

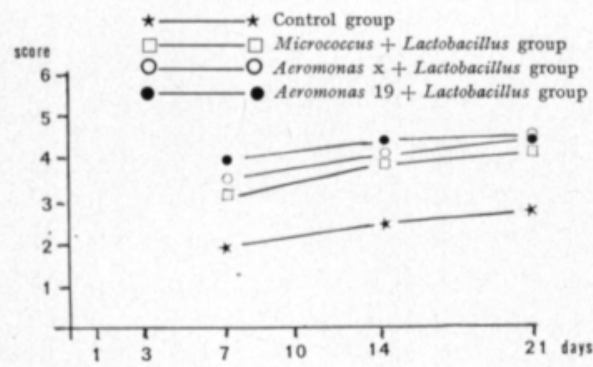

Figure 4. Effect of different bacterial inoculations on flavour of sausage.

$\begin{array}{lll}6 & 6 & 6 \\ 3.6 & 4.0 & 4.5 \\ 0.7 & 0.9 & 1.0\end{array}$

$\begin{array}{lll}4 & 4 & 3 \\ 2.5 & 3.7 & 3.3 \\ 1.1 & 1.1 & 1.0\end{array}$

sausages were better at the 0.05 significance level and Aeromonas 19 + Lactobacillus sausages better at the 0,001 significance level than Micrococcus + Lactobacillus sausages. However, Aeromonas $19+$ Lactobacillus samples were not significantly better than Aeromonas x + Lactobacillus samples. 
Table 8. Comparison of flavour of sausage pairs using the t-test. Scores for sausages of different ages are not separated.

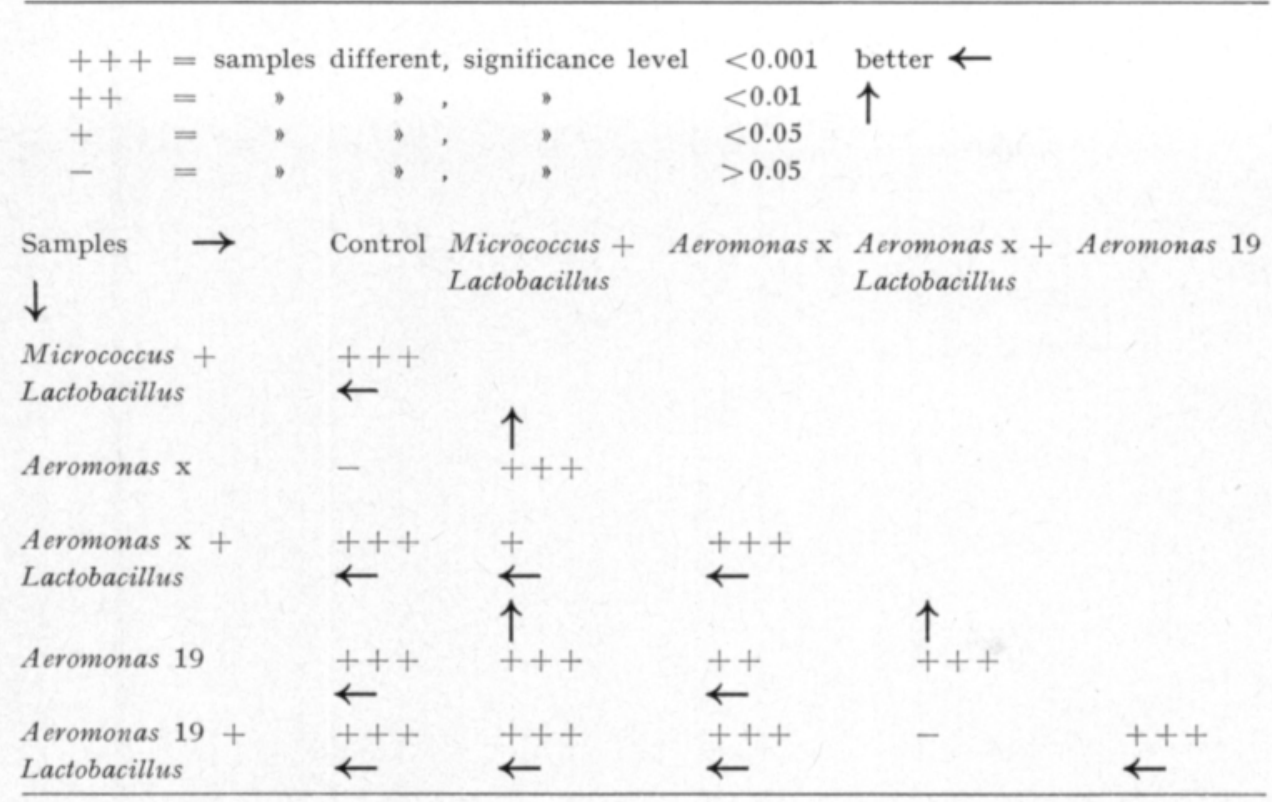

\section{4.1.2. Physical and chemical examinations}

3. 4. 1. 2. 1. $\mathrm{pH}$ value

a) Control group

The $\mathrm{pH}$ value of control sausages showed the slowest drop. However, in these experiments the mean $\mathrm{pH}$ value of 7 day old sausages was 5.33 (Fig. 5 and Table 9). The $\mathrm{pH}$ value $\mathbf{5 . 3 0}$ or lower was attained in $54.4 \%$ of 7 day old samples. During the next 2 weeks the $\mathrm{pH}$ decreased only slightly, the mean being 5.29 after 21 days of ripening. Fifty percent of the samples had a $\mathrm{pH}$ of 5.30 or lower.

\section{b) Micrococcus + Lactobacillus group}

The $\mathrm{pH}$ of Micrococcus + Lactobacillus sausages decreased so that its mean in 7 day old sausages was 5.20 (Fig. 5 and Table 9). $67.7 \%$ of samples that were only 3 days old attained a $\mathrm{pH}$ of 5.30 or lower. The $\mathrm{pH}$ changes during the next 2 weeks were small. The mean $\mathrm{pH}$ of 3 week old sausages was 5.11 and the $\mathrm{pH}$ of $86.7 \%$ of samples was 5.30 or lower.

\section{c) Aeromonas x group}

The $\mathrm{pH}$ of sausages inoculated with Aeromonas x strain was high throughout the ripening time, the mean always being over 5.30 (Table 9). Aeromonas x did not reduce the $\mathrm{pH}$ of dry sausage. 


\section{d) Aeromonas $\mathrm{x}+$ Lactobacillus group}

The $\mathrm{pH}$ of the Aeromonas $\mathrm{x}+$ Lactobacillus sausage group decreased more quickly than that of the Micrococcus + Lactobacillus group, the mean being 5.22 when the sausages were 3 days old (Fig. 5 and Table 9 ). $67.7 \%$ of the samples had a $\mathrm{pH}$ of 5.30 or lower. After 2 weeks the mean $\mathrm{pH}$ value was 4.97 and all samples had a $\mathrm{pH}$ value of $\mathbf{5 . 3 0}$ or lower.

\section{e) Aeromonas 19 group}

The $\mathrm{pH}$ of Aeromonas 19 sausages was lower than that of sausages inoculated with Aeromonas x. After 10 days of ripening the mean $\mathrm{pH}$ value was less than 5.30 , being 5.24 in 3 week old sausages (Table 9).

Table 9. Effect of bacterial inoculation on $\mathrm{pH}$ value of experimental sausages.

1. Control group

number of samples ............... 22

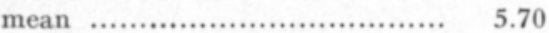

s.d.m. ................................ 0.11

$\%$ samples, $\mathrm{pH} \equiv 5.30$
20

5.70

0.12

0
22

5.58

0.18

9.1
22

5.33

0.17

54.5

22

5.30

0.15

46.5

22

5.25

20

$0.16 \quad 0.14$

$72.2 \quad 50.0$

2. Micrococcus + Lactobacillus

number of samples ............... 15

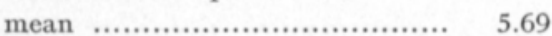

14

s.d.m.

$\%$ samples, $\mathrm{pH} \equiv 5.30$

3. Aeromonas $\mathrm{x}$

number of samples

mean

\section{4}

\section{4}

\section{4}

0.16

$\%$ samples, $\mathrm{pH} \equiv 5.30$

0

\subsection{0}

0.21

50.0

4. Aeromonas $\mathrm{x}+$ Lactobacillus

number of samples ..................

mean

$6 \quad 6$

6

\section{6}

$\%$ samples, $\mathrm{pH} \equiv 5.30$

67.7

0.19

0.19

4.97

5.07

83.3

83.3

0.20

0.15

5. Aeromonas 19

number of samples ................ 4

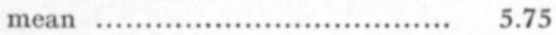

4

4

s.d.m.

$\%$ samples, $\mathrm{pH} \equiv 5.30$

\section{4}

5.32

0.27

50.0

4

5.28

0.20

50.0

100

100

6. Aeromonas $19+$ Lactobacillus

number of samples .................

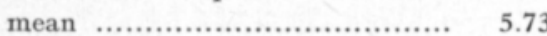

6

s.d.m.

$\%$ samples, $\mathrm{pH} \equiv 5.30 \ldots \ldots \ldots \ldots . . \quad 0$

0

83.3

0.14

5.04

5.07

s.d.m. = standard deviation of mean 


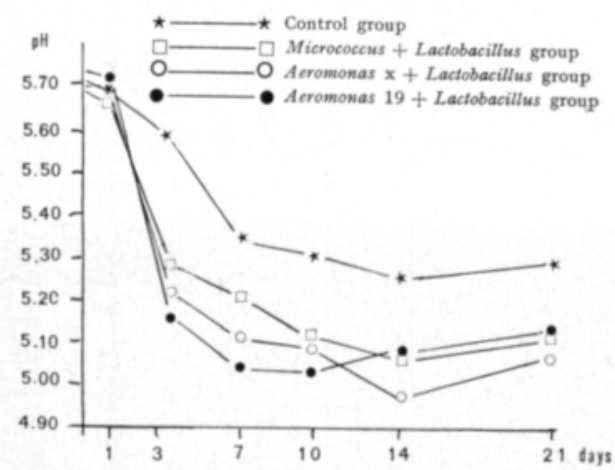

Figure 5. Effect of different bacterial inoculations on $\mathrm{pH}$ value of sausage. f) Aeromonas $19+$ Lactobacillus group

The decrease in $\mathrm{pH}$ value of Aeromonas $19+$ Lactobacillus sausages was quickest (Fig. 5 and Table 9). The mean $\mathrm{pH}$ value of 3 day old sausages was 5.16 and all the sausage samples attained $\mathrm{pH} 5.30$ or lower after 7 days of ripening. The $\mathrm{pH}$ differences were small during the next 2 weeks.

\section{4. 1.2.2. Consistency}

a) Control group

The consistency of control sausages developed slowly and was not firm enough. Some sausages reached a consistency value of $3 \mathrm{~kg}$ after 14 days and these comprised $53.8 \%$ of the total sample (Fig. 6 and Table 10). The mean consistency value of 21 day old sausages was $3.83 \mathrm{~kg}$.

\section{b) Micrococcus + Lactobacillus group}

The consistency of Micrococcus + Lactobacillus sausages was clearly firmer than that of control sausages. After 7 days $41.7 \%$ of samples attained a consistency value of $3 \mathrm{~kg}$ or over (Fig. 6 and Table 10). After 3 weeks of ripening the mean was $5.08 \mathrm{~kg}$.

\section{c) Aeromonas $\mathrm{x}$ group}

The consistency values of the control and Aeromonas $\mathrm{x}$ sausages were of the same order. Howevei, after 7 days of ripening the consistency values of $33.3 \%$ of Aeromonas $\mathrm{x}$ sausages were $3 \mathrm{~kg}$ or over (Table 10). Later the respective percentages were higher than those of the control group. The mean of 21 day old sausages was $3.86 \mathrm{~kg}$.

\section{d) Aeromonas $\mathrm{x}+$ Lactobacillus group}

After 3 days of ripening $50.0 \%$ of samples had a consistency value of $3 \mathrm{~kg}$ or over (Fig. 6 and Table 10). So the consistency can be said to develop more quickly in the Aeromonas $\mathrm{x}+$ Lactobacillus group than in the Micrococcus + Lactobacillus group. The mean consistency values were also higher throughout ripening with the exception of 3 week old sausages, where the mean for Micrococcus + Lactobacillus sausages was $0.24 \mathrm{~kg}$ higher, the mean for Aeromonas $\mathrm{x}$ + Lactobacillus sausages being 4.84 . 
Table 10. Effect of bacterial inoculations on consistency $(\mathrm{kg})$ of experimental sausages.

1 day

3 days

1. Control

7 days

10 day

14 days 21 days

number of samples .................... 10

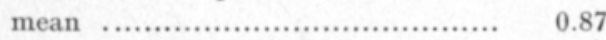

s.d.m. ...................................... 0.14

$\%$ samples, $\bar{一} 3 \mathrm{~kg}$

0.65

13

1.40

12

2. Micrococcus + Lactobacillus

number of samples .................... 11

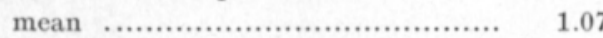

s.d.m. ................................... $\quad 0.39$

$\%$ samples, $>3 \mathrm{~kg}$

0

12

2.09

1.11

0

$\begin{array}{llc}3 & 3 & 3 \\ 1.45 & 1.68 & 2.57 \\ 0.45 & 0.72 & 0.42 \\ 0 & 0 & 33.3\end{array}$

3

2.55

0.73

13

11

2.37

13

2.53

3.32

3.83

0.88

0.65

3.21

53.8

0.93

90.9

3. Aeromonas $\mathrm{x}$

number of samples

mean

s.d.m.

0

66.7

13

12

3.58

4.51

5.08

1.36

1.16

1.34

1.41

$92.3 \quad 100$

$\%$ samples, $\lesseqgtr 3 \mathrm{~kg}$

4. Aeromonas $\mathrm{x}+$ Lactobacillus

number of samples .....................

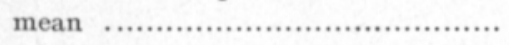

s.d.m. .

34

1.35

0.45

2.61

\section{4}

4.17

2.68

$\%$ samples, $\lesseqgtr 3 \mathrm{~kg}$

$0 \quad 50.0$

4
3.98
1.12
75.0

$\begin{array}{lc}3 & 3 \\ 3.82 & 3.86 \\ 0.43 & 1.36 \\ 66.7 & 100\end{array}$

5. Aeromonas 19

\begin{tabular}{|c|c|c|c|c|c|c|}
\hline number of samples ...................... & 4 & 4 & 4 & 4 & 4 & 3 \\
\hline mean & 0.88 & 1.06 & 1.62 & 2.18 & 2.93 & 3.83 \\
\hline s.d.m. .................................... & 0.11 & 0.11 & 0.51 & 0.76 & 0.60 & 0.74 \\
\hline$\%$ samples, $\overline{\text { s }} 3 \mathrm{~kg} \ldots \ldots \ldots \ldots \ldots \ldots$ & 0 & 0 & 0 & 0 & 75.0 & 100 \\
\hline \multicolumn{7}{|l|}{ Aeromonas $19+$ Lactobacillus } \\
\hline 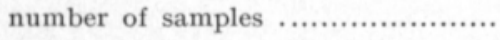 & 6 & 6 & 6 & 6 & 6 & 5 \\
\hline 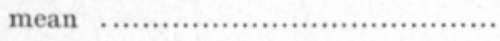 & 0.86 & 1.86 & 2.91 & 3.27 & 3.78 & 4.74 \\
\hline 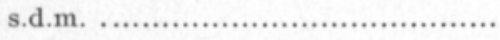 & 0.13 & 0.33 & 0.73 & 1.05 & 1.00 & 1.38 \\
\hline$\%$ samples, $\equiv 3 \mathrm{~kg} \quad \ldots \ldots \ldots \ldots \ldots \ldots \ldots$ & 0 & 0 & 16.7 & 66.7 & 83.3 & 100 \\
\hline
\end{tabular}

s.d.m. = standard deviation of mean

\section{e) Aeromonas 19 group}

The consistency values stayed under $3 \mathrm{~kg}$ during the first 10 days of ripening, until after 2 weeks $75.0 \%$ of samples had values over $3 \mathrm{~kg}$. The sausages of this group were softest throughout ripening up to 3 weeks when the mean consistency value was the same as that of the sausages of the control group $-3.83 \mathrm{~kg}$ (Table 10).

\section{f) Aeromonas $19+$ Lactobacillus group}

In Aeromonas $19+$ Lactobacillus sausages the consistency developed surprisingly slowly especially at the beginning of ripening. After 7 days only $16.7 \%$ 


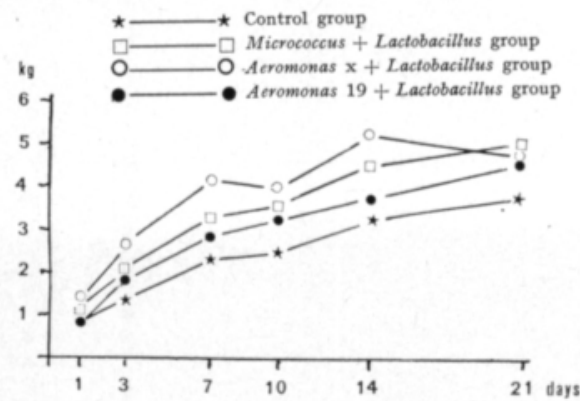

Figure 6. Etfect of different bacterial inoculations on consistency (determined by Instron apparatus) of sausage. of sausages had attained the consistency value of $3 \mathrm{~kg}$ or over (Fig. 6 and Table 10). The corresponding percentage in Micrococcus + Lactobacillus sausages was 41.7 and in Aeromonas $\mathrm{x}+$ Lactobacillus sausages 75.0. After 21 days the mean consistency value of Aeromonas $19+$ Lactobacillus sausages was 4.74 being $0.34 \mathrm{~kg}$ lower than that of Micrococcus + Lactobacillus sausages.

\section{4. 1. 2. 3. Weight losses}

The mean weight losses for each sausage group are presented in table 11 . The table shows that the weight losses for each group developed similarly. The ranges of the means for all sausage groups are as follows:

Table 11. Percentile weight losses of experimental sansages.

\begin{tabular}{|c|c|c|c|c|c|c|}
\hline Sausage group & 1 day & 3 days & 7 days & 10 days & 14 days & 21 days \\
\hline \multicolumn{7}{|l|}{ Control } \\
\hline number of samples . .................... & 12 & 15 & 13 & 16 & 17 & 14 \\
\hline 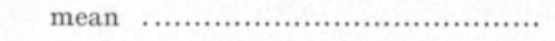 & 2.6 & 7.1 & 13.9 & 17.1 & 19.0 & 24.6 \\
\hline 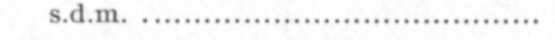 & 1.0 & 1.8 & 2.3 & 3.1 & 4.4 & 3.6 \\
\hline \multicolumn{7}{|l|}{ 2. Micrococcus + Lactobacillus } \\
\hline number of samples...$\ldots \ldots \ldots \ldots \ldots \ldots \ldots$ & 10 & 16 & 13 & 16 & 15 & 12 \\
\hline 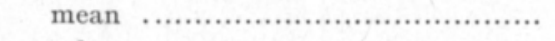 & 2.7 & 8.4 & 14.1 & 17.8 & 20.6 & 25.4 \\
\hline s.d.m. ...................................... & 1.0 & 2.1 & 1.4 & 2.1 & 2.7 & 2.8 \\
\hline \multicolumn{7}{|l|}{ 3. Aeromonas $\mathrm{x}$} \\
\hline number of samples ...................... & 4 & 5 & 5 & 5 & 4 & 5 \\
\hline 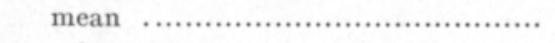 & 2.5 & 7.8 & 15.3 & 18.0 & 20.6 & 26.0 \\
\hline s.d.m. . ..................................... & 1.0 & 2.1 & 2.3 & 3.2 & 4.9 & 2.8 \\
\hline \multicolumn{7}{|l|}{ 4. Aeromonas $\mathrm{x}+$ Lactobacillus } \\
\hline 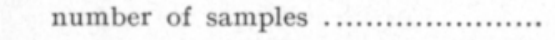 & 5 & 6 & 6 & 6 & 5 & 5 \\
\hline 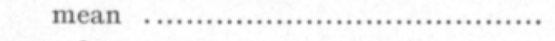 & 3.3 & 8.3 & 15.2 & 18.9 & 20.5 & 25.3 \\
\hline 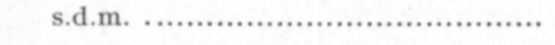 & 1.4 & 2.3 & 2.5 & 2.4 & 1.7 & 6.1 \\
\hline \multicolumn{7}{|l|}{ 5. Aeromonas 19} \\
\hline number of samples ....................... & 3 & 4 & 4 & 3 & 3 & 3 \\
\hline 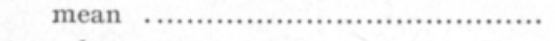 & 3.0 & 7.8 & 13.5 & 17.2 & 20.5 & 24.9 \\
\hline 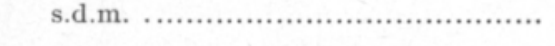 & 0.6 & 1.9 & 1.5 & 1.0 & 2.6 & 1.0 \\
\hline \multicolumn{7}{|l|}{ 6. Aeromonas $19+$ Lactobacillus } \\
\hline number of samples $\ldots \ldots \ldots \ldots \ldots \ldots \ldots$ & 5 & 6 & 6 & 6 & 5 & 5 \\
\hline 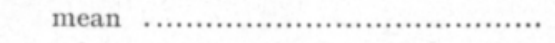 & 3.3 & 8.8 & 14.5 & 18.1 & 22.4 & 26.7 \\
\hline 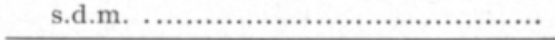 & 1.5 & 2.2 & 1.6 & 2.0 & 1.6 & 0.8 \\
\hline
\end{tabular}

s.d.m. = standard deviation of mean 
1 day 3 days 7 days 10 days 14 days 21 days

$2.5-3.3 \% \quad 7.1-8.8 \% \quad 13.5-15.3 \% \quad 17.1-18.9 \% \quad 19.0-22.4 \% \quad 24.6-26.7 \%$

When the control sausages ripen for 3 weeks and Micrococcus + Lactobacillus, Aeromonas x + Lactobacillus and Aeromonas $19+$ Lactobacillus sausages ripen for 10 days, the weight losses during ripening can, in the last 3 cases, be considerably reduced. The following mean weight losses for ripened sausages can be taken from table 11:

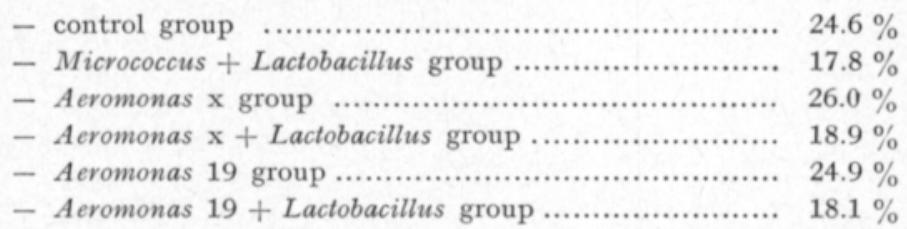

It was sometimes found that in the control, Aeromonas $\mathrm{x}$ and Aeromonas 19 groups the sausages did not always ripen within 3 weeks.

\section{4. 1. 2. 4. Nitrite}

The nitrite content of experimental sausages rose during the first 3 days of ripening so that the percentages of samples containing $30 \mathrm{ppm}$ or more of sodium nitrite for the different sausage groups were as follows:

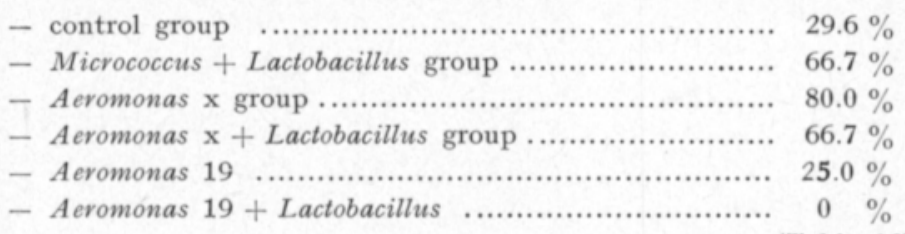

(Table 12).

The highest mean nitrite values after 3 days of ripening were found in sausages inoculated with Aeromonas x (56.5 ppm), Aeromonas x + Lactobacillus (37.2 ppm) and Micrococcus + Lactobacillus (34.1 ppm) (Table 12). Even the control sausages contained $25.6 \mathrm{ppm}$ sodium nitrite while Aeromonas 19 sausages contained only $12.0 \mathrm{ppm}$ and Aeromonas $19+$ Lactobacillus sausages only $9.4 \mathrm{ppm}$. After 3 days of ripening nitrite concentrations decreased

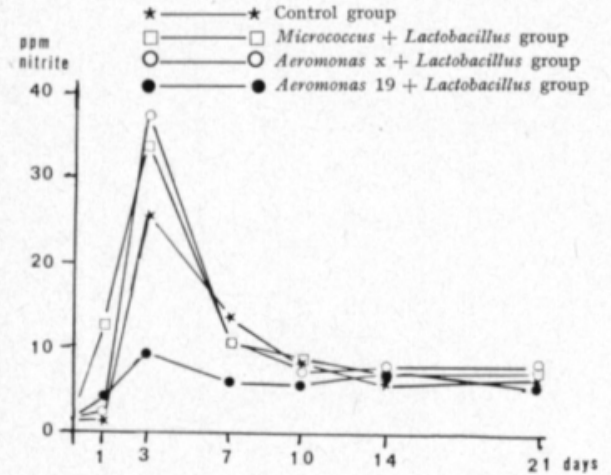

Figure 7. Effect of different bacterial inoculations on sodium nitrite content of sausage. so that 7 day old sausages contained about $10 \mathrm{ppm}$ sodium nitrite. During the next 2 weeks there was a small decrease in nitrite concentration in all sausage groups (Fig. 7 and Table 12). The results can be interpreted as showing that Aeromonas x and Micrococcus are effective nitrate reducers. On the other hand the content of nitrate is also lower in Aeromonas $19+$ Lactobacillus sausages (p. 145). Consequently Aeromonas 19 could be regarded as a stronger nitrate reducer. 
Table 12. Effect of bacterial inoculations on sodium nitrite content (ppm) of experimental sausages.

Sausage group $\quad 0$ days 1 day 3 days 7 days 10 days 14 days 21 days

1. Control

number of samples ...................

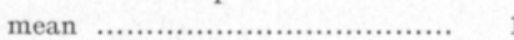

s.d.m. ..................................

$\%$ samples, $₹ 30 \mathrm{ppm}$.............

$\begin{array}{lcccccc}20 & 19 & 21 & 21 & 22 & 22 & 20 \\ 1.0 & 1.4 & 25.6 & 13.3 & 8.0 & 6.4 & 6.4 \\ 0.7 & 1.3 & 25.0 & 9.4 & 3.5 & 3.7 & 3.0 \\ 0 & 0 & 29.6 & 0 & 0 & 0 & 0\end{array}$

2. Micrococcus + Lactobacillus

number of samples .................

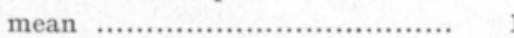

s.d.m. .................................. 1.2

$\%$ samples, $₹ 30 \mathrm{ppm}$..............

$\begin{array}{lllcccc}15 & 14 & 15 & 15 & 15 & 15 & 14 \\ 1.4 & 12.5 & 34.1 & 10.4 & 8.6 & 7.0 & 6.9 \\ 1.2 & 20.8 & 18.0 & 5.4 & 3.7 & 2.9 & 3.6 \\ 0 & 14.4 & 66.7 & 0 & 0 & 0 & 0\end{array}$

3. Aeromonas $\mathrm{x}$

number of samples ...................

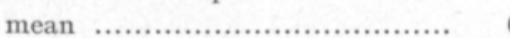

s.d.m. ...................................

$\%$ samples, $\lesseqgtr 30 \mathrm{ppm}$.............

0.8

5

$\begin{array}{ccll}5 & 5 & 5 & 5 \\ 13.3 & 12.8 & 9.6 & 8.7 \\ 9.3 & 7.5 & 4.7 & 3.3 \\ 0 & 0 & 0 & 0\end{array}$

4. Aeromonas $\mathrm{x}+$ Lactobacillus

number of samples ....................

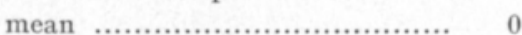

s.d.m. ..................................... 0 .

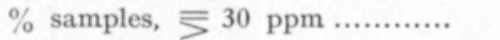

0.8

.8

$1.8 \quad 37$

6

6

6

6

6

$1.7 \quad 24.6$

10.1

7.5

8.2

$\begin{array}{ll}0 & 66.7\end{array}$

3.6

4.0

5. Aeromonas 19

number of samples ..................

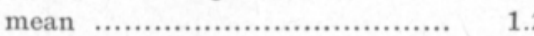

s.d.m. .................................. 0.5

$\%$ samples, $\$ 30 \mathrm{ppm}$............

$\begin{array}{llcclll}4 & 4 & 4 & 4 & 4 & 4 & 4 \\ 1.2 & 8.0 & 12.0 & 11.1 & 5.5 & 7.6 & 6.5 \\ 0.5 & 7.0 & 12.6 & 11.3 & 1.4 & 3.9 & 5.1 \\ 0 & 0 & 25.0 & 25.0 & 0 & 0 & 0\end{array}$

6. Aeromonas $\mathbf{1 9}+$ Lactobacillus

number of samples .................

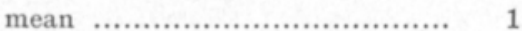

s.d.m. .................................. 0.5

5.5

$\%$ samples, $\equiv 30 \mathrm{ppm} \ldots \ldots \ldots \ldots . . .$.

s.d.m. = standard deviation of mean

\section{4. 1. 2. 5. Nitrate}

The potassium nitrate content decreased most markedly in sausag $s$ inoculated with lactobacilli. After one day the means were as follows:

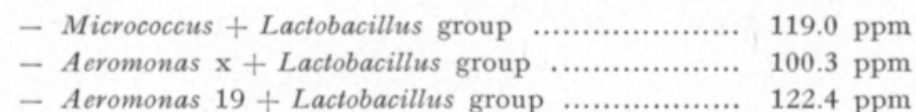

- Aeromonas $19+$ Lactobacillus group ................ 122.4 ppm

(Table 13).

The mean potassium nitrate contents of other samples after one day of ripening were as follows:

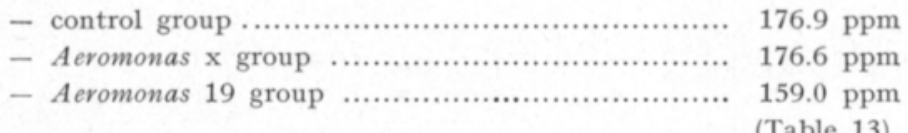

(Table 13). 
Table 13. Effect of bacterial inoculations on potassium nitrate content (ppm) of experimental sausages.

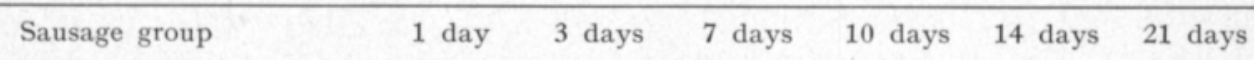

1. Control

\begin{tabular}{|c|c|c|c|c|c|}
\hline 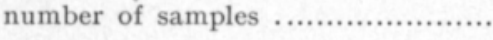 & 13 & 11 & 13 & 11 & 14 \\
\hline 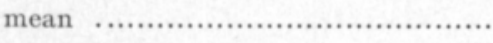 & 176.9 & 179.7 & 82.8 & 97.8 & 64.7 \\
\hline s.d.m. . & 55.3 & 62.0 & 43.8 & 54.8 & 41.7 \\
\hline
\end{tabular}

2. Micrococcus + Lactobacillus

\begin{tabular}{|c|c|c|c|c|c|}
\hline umber of s & 11 & 12 & 12 & 13 & 12 \\
\hline & 119.0 & 106.0 & 86.6 & 54.9 & 42.8 \\
\hline 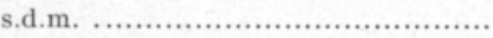 & 39.0 & 32.4 & 43.3 & 37.7 & 22.9 \\
\hline
\end{tabular}

3. Aeromonas $\mathrm{x}$

number of samples ......................

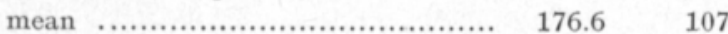

$65.5 \quad 73.0$

6
90.8

$4 \quad 6$

s.d.m.

4. Aeromonas $\mathrm{x}+$ Lactobacillus

number of samples

$\begin{array}{rrrrrr}6 & 7 & 7 & 7 & 6 & 6 \\ 100.3 & 115.1 & 73.7 & 71.0 & 36.7 & 46.5 \\ 33.1 & 35.8 & 18.9 & 26.5 & 13.5 & 30.0\end{array}$

s.d.m.

5. Aeromonas 19

number of samples

\begin{tabular}{rccccc}
\multicolumn{1}{c}{3} & 3 & 3 & 3 & 3 & 3 \\
159.0 & 99.7 & 55.3 & 57.7 & 44.7 & 55.3 \\
18.7 & 70.5 & 38.3 & 33.7 & 5.5 & 45.2
\end{tabular}

s.d.m.

70.5

38.3

33.7

6. Aeromonas $19+$ Lactobacillus

\begin{tabular}{|c|c|c|c|c|c|c|}
\hline number of samples ... & 5 & 5 & 6 & 6 & 5 & 5 \\
\hline 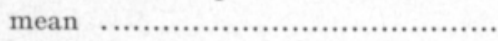 & 122.4 & 72.4 & 68.2 & 49.0 & 50.6 & 33.2 \\
\hline 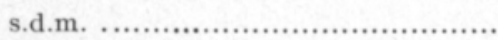 & 27.1 & 26.8 & 50.5 & 37.0 & 33.0 & 24.9 \\
\hline
\end{tabular}

s.d.m. = standard deviation of mean

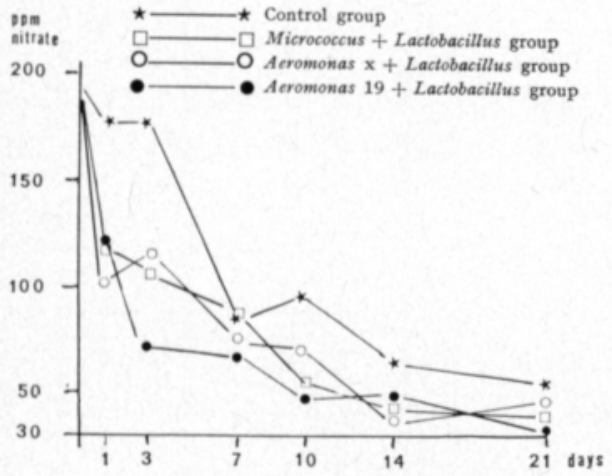

Figure 8. Effect of different bacterial inoculations on potassium nitrate content of sausage.
The potassium nitrate concentration decreased throughout the time of ripening in sausages inoculated with lactobacilli and some other bacteria (Fig. 8). After 3 weeks of ripening the lowest mean values were in these sausages the values being as follows:

$$
\begin{aligned}
& \text { - Micrococcus + Lactobacillus group } \\
& \text { - Aeromonas } \mathrm{x}+\text { Lactobacillus group } \\
& 39.1 \mathrm{ppm} \\
& \text { - Aeromonas } 19+\text { Lactobacillus group }
\end{aligned}
$$


The mean potassium nitrate contents in other sausages after 3 weeks of ripening were as follows:

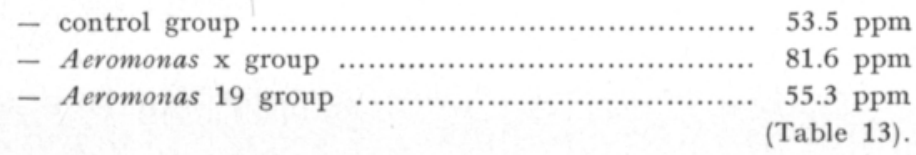

\section{4.1.3. Microbiological examinations}

\section{4. 1. 3. 1. Total bacteria}

The results of total bacterial counts are presented in Fig. 9 and Table 14. On the first day of ripening there was little or no increase in numbers of bacteria in any of the sausage groups. During the next 2 days the essential growth of bacterial counts took place in all groups. After that the total bacterial counts stayed at the same level or changed only slightly. The highest numbers of bacteria were in the sausages of Aeromonas x + Lactobacillus and Aeromonas 19

Table 14. Number of bacteria $\times 10^{6} / \mathrm{g}$ on plate count agar in different sausage groups.

\begin{tabular}{llllllllll}
\hline Sausage group & 0 days & 1 day & 3 days & 7 days & 10 & days & 14 days & 21 days
\end{tabular}

1. Control

\begin{tabular}{|c|c|c|c|c|c|c|c|}
\hline number of samples ... & 15 & 14 & 15 & 14 & 15 & 15 & 14 \\
\hline 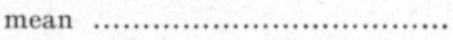 & 3.2 & 2.7 & 82.6 & 86.4 & 70.5 & 59.9 & 66.9 \\
\hline 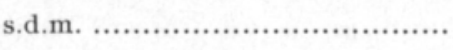 & 4.6 & 3.8 & 84.0 & 69.9 & 41.2 & 46.2 & 40.3 \\
\hline \multicolumn{8}{|l|}{ Micrococcus + Lactobacillus } \\
\hline number of samples .................. & 10 & 13 & 13 & 14 & 14 & 13 & 12 \\
\hline 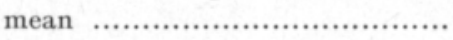 & 16.4 & 23.1 & 135.1 & 143.6 & 92.5 & 77.4 & 77.7 \\
\hline 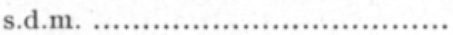 & 8.3 & 15.4 & 107.0 & 145.2 & 71.6 & 52.3 & 70.0 \\
\hline
\end{tabular}

3. Aeromonas $\mathrm{x}$

number of samples ..................

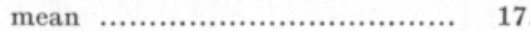

$\begin{array}{ccccccc}4 & 4 & 4 & 4 & 4 & 4 & 4 \\ 17.3 & 17.3 & 38.8 & 92.5 & 65.3 & 71.4 & 65.7 \\ 10.9 & 10.2 & 54.3 & 80.2 & 52.4 & 68.1 & 25.5\end{array}$

4. Aeromonas $\mathrm{x}+$ Lactobacillus

number of samples .................

mean $\ldots \ldots \ldots \ldots \ldots \ldots \ldots \ldots \ldots \ldots \ldots \ldots \ldots, 16.7$

$\begin{array}{rrrrrrr}6 & 6 & 6 & 6 & 6 & 6 & 6\end{array}$

s.d.m.

$16.7 \quad 12.7$

5. Aeromonas 19

number of samples

\begin{tabular}{rrrrrrc}
\multicolumn{1}{c}{4} & \multicolumn{1}{c}{4} & 3 & 4 & 3 & 4 & 3 \\
12.0 & 12.5 & 49.0 & 42.8 & 39.7 & 69.8 & 213.3 \\
4.6 & 3.4 & 5.6 & 12.7 & 15.6 & 65.2 & 161.7
\end{tabular}

s.d.m.

12.7

6. Aeromonas $19+$ Lactobacillus

number of samples ..................

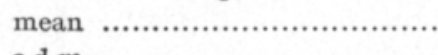

\begin{tabular}{rcccccc}
6 & 6 & 6 & 6 & 6 & 6 & 5 \\
15.0 & 36.0 & 350.0 & 360.0 & 391.0 & 264.8 & 698.0 \\
7.6 & 39.8 & 284.7 & 152.2 & 352.6 & 170.8 & 436.0 \\
\hline
\end{tabular}

s.d.m. = standard deviation of mean 


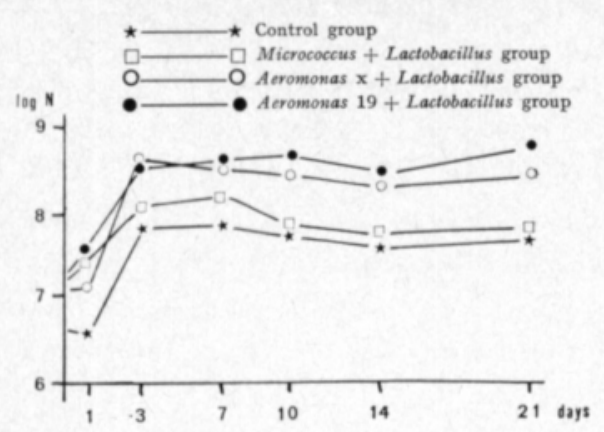

Figure 9. Number of bacteria/g on plate count agar in different sausage groups.
+ Lactobacillus groups, with mean values well over $10^{8} / \mathrm{g}$. In the Micrococcus + Lactobacillus group the mean bacterial count increased to a little over $10^{8} / \mathrm{g}$ during the first 3 days of ripening and decreased to less than $10^{8} / \mathrm{g}$ after 7 days of ripening. The control sausages contained slightly fewer bacteria than the sausages inoculated with micrococci and lactobacilli. The bacterial counts

of Aeromonas x and Aeromonas 19 sausages remained between $10^{7} / \mathrm{g}$ and $2 \times$ $10^{8} / \mathrm{g}$ throughout ripening. The reason is that they did not contain inoculated lactobacilli.

\section{4. 1. 3. 2. Micrococci}

Mannitol salt agar was used to determine, in particular, the number of inoculated micrococci. Staphylococci also grow on this medium, and this must be borne in mind when checking the results.

Table 15. Number of micrococci $\times 10^{4} / \mathrm{g}$ on mannitol salt agar in different sausage groups.

\begin{tabular}{|c|c|c|c|c|c|c|c|c|}
\hline & Sausage group & 0 days & 1 day & 3 days & 7 days & 10 days & 14 days & 21 days \\
\hline & Control & & & & & & & \\
\hline & number of samples ................... & 20 & 19 & 17 & 14 & 19 & 15 & 17 \\
\hline & 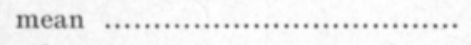 & 7.5 & 6.0 & 14.9 & 33.2 & 10.0 & 5.1 & 8.7 \\
\hline & s.d.m. .................................. & 11.9 & 6.6 & 13.7 & 33.6 & 11.5 & 6.9 & 11.3 \\
\hline \multirow[t]{4}{*}{2.} & Micrococcus + Lactobacillus & & & & & & & \\
\hline & number of samples ................... & 15 & 13 & 14 & 15 & 15 & 14 & 14 \\
\hline & 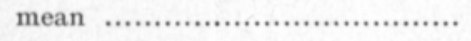 & 870 & 1267 & 1607 & 1240 & 1547 & 1593 & 1293 \\
\hline & 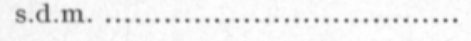 & 566 & 849 & 1440 & 771 & 1164 & 1408 & 975 \\
\hline \multirow[t]{4}{*}{3.} & Aeromonas $\mathrm{x}$ & & & & & & & \\
\hline & number of samples ................... & 5 & 5 & 5 & 5 & 5 & 5 & 5 \\
\hline & 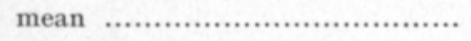 & 1.5 & 2.9 & 1.9 & 3.4 & 4.3 & 4.2 & 4.5 \\
\hline & 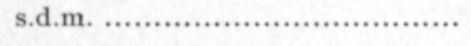 & 1.2 & 2.1 & 1.1 & 3.3 & 4.7 & 2.3 & 4.5 \\
\hline \multirow[t]{4}{*}{4.} & Aeromonas $\mathbf{x}+$ Lactobacillus & & & & & & & \\
\hline & number of samples ................... & 6 & 6 & 6 & 6 & 6 & 6 & 6 \\
\hline & 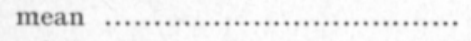 & 3.1 & 3.3 & 3.3 & 2.1 & 1.4 & 0.9 & 0.3 \\
\hline & 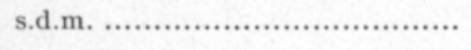 & 3.0 & 3.2 & 3.0 & 2.4 & 1.7 & 0.9 & 0.2 \\
\hline \multirow[t]{4}{*}{5.} & Aeromonas 19 & & & & & & & \\
\hline & number of samples ................... & 4 & 4 & 4 & 4 & 4 & 4 & 4 \\
\hline & 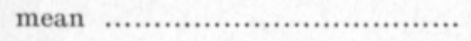 & 7.5 & 23.3 & 10.6 & 23.3 & 1.9 & 3.6 & 4.8 \\
\hline & s.d.m. .................................... & 10.4 & 24.5 & 8.8 & 24.4 & 1.4 & 2.6 & 4.7 \\
\hline \multirow[t]{4}{*}{6.} & Aeromonas $19+$ Lactobacillus & & & & & & & \\
\hline & number of samples ................... & 6 & 6 & 6 & 6 & 6 & 6 & 4 \\
\hline & 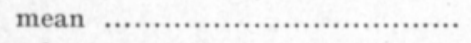 & 7.3 & 4.4 & 4.1 & 0.8 & 2.1 & 2.7 & 0.6 \\
\hline & s.d.m. .................................. & 9.0 & 3.4 & 4.9 & 0.7 & 2.2 & 2.5 & 0.8 \\
\hline
\end{tabular}

s.d.m. = standard deviation of mean 


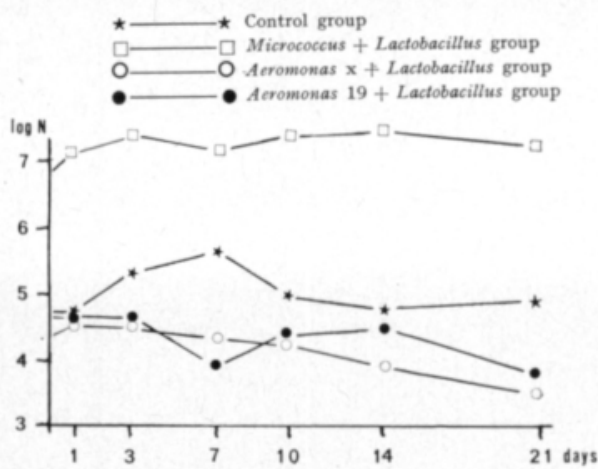

Figure 10. Number of micrococci/g on mannitol salt agar in different sausage groups.
The number of micrococci in control sausages was about $10^{5} / \mathrm{g}$ throughout ripening (Fig. 10). The sausages inoculated with micrococci and lactobacilli contained the most micrococci. Throughout ripening the mean count was a little over $10^{7} / \mathrm{g}$. The number of micrococci in Aeromonas $\mathrm{x}+$ Lactobacillus and Aeromonas $19+$ Lactobacillus sausages decreased from about $5 \times 10^{4} / \mathrm{g}$ to about $5 \times 10^{3} / \mathrm{g}$ during ripening (Fig. 10 and Table 15). The mean micrococcus count of Aeromonas x sausages stayed between $10^{4} / \mathrm{g}$ and $5 \times 10^{4} / \mathrm{g}$ while that of Aeromonas 19 sausages exceeded $10^{5} / \mathrm{g}$ after one day and stayed there about one week before falling back to between $10^{1} / \mathrm{g}$ and $10^{5} / \mathrm{g}$.

\section{4. 1. 3. 3. Total bacteria on tributyrine agar}

The total number of bacteria in control sausages remained lower on tributyrine agar than on plate count agar, the mean lying between $10^{6} / \mathrm{g}$ and $10^{7} / \mathrm{g}$ throughout ripening (Figs. 9, 11 and Tables 14, 16). The total bacterial count

Table 16. Number of bacteria $\times 10^{6} / \mathrm{g}$ on tributyrine agar in different sausage groups.

\begin{tabular}{|c|c|c|c|c|c|c|c|c|}
\hline & Sausage group & 0 days & 1 day & 3 days & 7 days & 10 days & 14 days & 21 days \\
\hline \multicolumn{9}{|c|}{ 1. Control } \\
\hline & number of samples .................. & 19 & 16 & 21 & 15 & 22 & 21 & 21 \\
\hline & 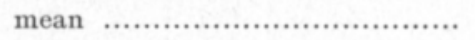 & 1.4 & 1.3 & 7.1 & 10.0 & 7.1 & 4.9 & 6.2 \\
\hline & s.d.m. ................................ & 1.2 & 1.5 & 8.9 & 9.1 & 4.7 & 6.8 & 7.2 \\
\hline \multicolumn{9}{|c|}{ 2. Micrococcus + Lactobacillus } \\
\hline & number of samples .................. & 15 & 14 & 15 & 13 & 14 & 13 & 14 \\
\hline & 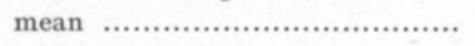 & 8.1 & 11.2 & 14.5 & 11.1 & 6.6 & 7.0 & 6.0 \\
\hline & s.d.m. ................................ & 5.2 & 9.1 & 13.3 & 9.0 & 3.5 & 4.3 & 4.7 \\
\hline \multicolumn{9}{|c|}{ 3. Aeromonas $\mathrm{x}$} \\
\hline & number of samples .................. & 5 & 5 & 5 & 5 & 5 & 5 & 5 \\
\hline & 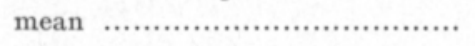 & 12.5 & 43.8 & 45.4 & 38.2 & 59.2 & 39.8 & 35.6 \\
\hline & s.d.m. ............................... & 8.7 & 36.3 & 27.9 & 27.9 & 55.2 & 27.7 & 24.3 \\
\hline \multicolumn{9}{|c|}{ 4. Aeromonas $\mathrm{x}+$ Lactobacillus } \\
\hline & number of samples ................. & 6 & 6 & 6 & 6 & 6 & 5 & 4 \\
\hline & 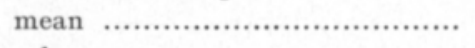 & 20.6 & 33.8 & 57.0 & 10.6 & 7.1 & 4.0 & 2.1 \\
\hline & s.d.m. ............................... & 17.1 & 13.0 & 50.0 & 3.7 & 4.8 & 3.0 & 3.3 \\
\hline \multicolumn{9}{|c|}{ 5. Aeromonas 19} \\
\hline & number of samples .................. & 4 & 4 & 3 & 4 & 4 & 4 & 3 \\
\hline & 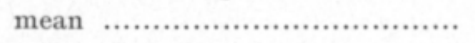 & 22.1 & 28.0 & 10.8 & 35.5 & 45.8 & 49.1 & 25.0 \\
\hline & s.d.m. ............................... & 13.8 & 6.5 & 8.0 & 28.8 & 46.0 & 52.2 & 15.0 \\
\hline \multicolumn{9}{|c|}{ 6. Aeromonas $19+$ Lactobacillus } \\
\hline & number of samples ................. & 6 & 5 & 6 & 6 & 6 & 6 & 5 \\
\hline & 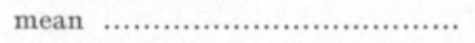 & 32.0 & 23.0 & 49.2 & 13.3 & 132.1 & 78.6 & 20.2 \\
\hline & s.d.m. ................................ & 32.0 & 11.8 & 36.9 & 12.7 & 151.7 & 87.2 & 19.3 \\
\hline
\end{tabular}

s.d.m. = standard deviation of mean 
of Micrococcus + Lactobacillus sausages on tributyrine agar reflects most closely the number of micrococci. The mean count first rose to a little over $10^{7} / \mathrm{g}$ and then fell to less than $10^{7} / \mathrm{g}$ after one week. On mannitol salt agar the mean count remained in excess of $10^{7} / \mathrm{g}$.

The mean bacterial count of Aeromonas $\mathrm{x}+$ Lactobacillus sausages increased from about $2 \times 10^{7} / \mathrm{g}$ to about $5 \times 10^{7} / \mathrm{g}$ during the first 3 days of ripening

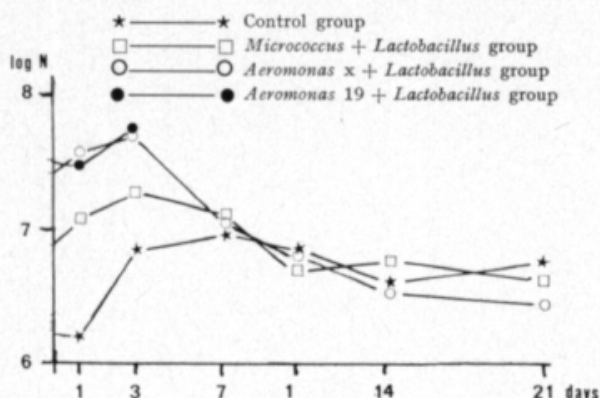

Figure 11. Number of bacteria/g on tributyrine agar in different sausage groups.

(Fig. 11 and Table 16). Thereafter the count fell to less than $10^{7} / \mathrm{g}$ and after 3 weeks of ripening was around $10^{6} / \mathrm{g}$. The total number of bacteria in Aeromonas $19+$ Lactobacillus sausages ranged between $10^{7} / \mathrm{g}$ and $10^{8} / \mathrm{g}$ during ripening. The numbers of bacteria shown greatly resemble the lipolytic bacterial count ( $=$ inoculated Aeromonas bacteria) because lactobacilli do not grow on tributyrine agar (Fig. 11 and Table 16). The mean quantity of bacteria in the Aeromonas $\mathrm{x}$ and Aeromonas 19 sausage groups varied between $10^{7} / \mathrm{g}$ and $6 \times 10^{7} / \mathrm{g}$ during ripening.

\section{4. 1. 3. 4. Lipolytic bacteria}

The sausage was cultivated on tributyrine agar to determine the number of inoculated Aeromonas strains. In the sausages inoculated with Aeromonas x + Lactobacillus and Aeromonas $19+$ Lactobacillus the mean lipolytic bacterial counts decreased from about $2 \times 10^{7} / \mathrm{g}$ to about $2.5 \times 10^{6} / \mathrm{g}$ during ripening (Fig. 12 and Table 17). The numbers of strain $\mathrm{x}$ were a little smaller than those of strain 19. The mean quantity of lipolytic bacteria in sausages inoculated

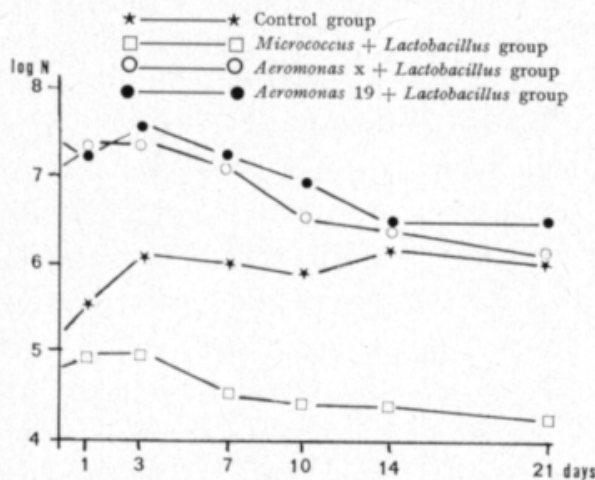

Figure 12. Number of lipolytic bacteria/g on tributyrine agar in different sausage groups. with Aeromonas x and Aeromonas 19 varied between $10^{7} / \mathrm{g}$ and $5 \times 10^{7} / \mathrm{g}$ (Table 17).

The mean lipolytic bacterial counts in the control sausages rose from about $10^{5} / \mathrm{g}$ to about $10^{6} / \mathrm{g}$ during the first 3 days of ripening and then remained at a level of $10^{6} / \mathrm{g}$ (Fig. 12 and Table 17). The number of lipolytic bacteria varied between $10^{5} / \mathrm{g}$ and $10^{4} / \mathrm{g}$ in Micrococcus + Lactobacillus sausages during ripening. 
Table 17. Number of lipolytic bacteria $\times 10^{6} / \mathrm{g}$ on tributyrine agar in different sausage groups.

Sausage group
0 days

1 day
7 days

10 days 14 days 21 days

1. Control

number of samples

mean

19

s.d.m.

0.2

17

0.4

19

0.3

1.2

1.3

19

1.0

19

0.8

19

2.0

2.4

1.4

1.5

19

2. Micrococcus + Lactobacillus

number of samples ...

$\begin{array}{ccccccc}12 & 13 & 14 & 11 & 13 & 11 & 14 \\ 0.07 & 0.09 & 0.1 & 0.04 & 0.03 & 0.03 & 0.02 \\ 0.1 & 0.2 & 0.2 & 0.06 & 0.07 & 0.04 & 0.03\end{array}$

s.d.m.

0.1

0.2

0.2

0.06

3. Aeromonas $\mathrm{x}$

number of samples .

mean

5

5

26.2

5

5

5

5

4

s.d.m.

14.3

19.9

42.2

32.6

17.6

16.2

4.7

$27.0 \quad 26.7$

11.4

14.7

7.0

4. Aeromonas $\mathrm{x}+$ Lactobacillus

number of samples

$6 \quad 6$

mean

14.8

6

6

25.8

30.2

6

6

6

6

s.d.m.

11.2

17.8

27.9

11.2

3.8

2.4

1.2

5.0

2.5

2.2

2.2

5. Aeromonas 19

number of samples

$\begin{array}{lll}4 & 4 & 3\end{array}$

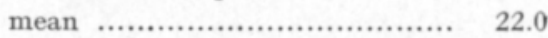

4

3
41.0

4

4

4

3

s.d.m.

13.9

6.5

15.0

35.5

35.3

9.1

25.5

28.8

35.5

6.8

30.4

6. Aeromonas $\mathbf{1 9}+$ Lactobacillus

number of samples .................

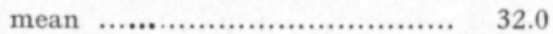

5

23.0

6

49.2

6

6

6

5

s.d.m. ............................... 31.4

$11.8 \quad 36.9$

18.5

9.4

s.d.m. = standard deviation of mean

\section{4. 1. 3. 5. Lactobacilli}

The mean lactobacillus counts of the control sausages rose steeply during the first 3 days of ripening from $5 \times 10^{3} / \mathrm{g}$ to $4 \times 10^{7} / \mathrm{g}$ and ranged between

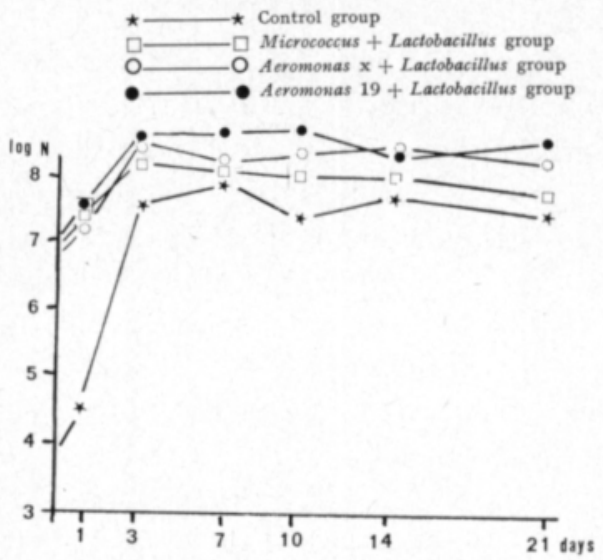

Figure 13. Number of lactobacilli/g on Rogosa agar in different sausage groups.
$10^{7} / \mathrm{g}$ and $10^{8} / \mathrm{g}$ for the rest of the ripening time (Fig. 13 and Table 18). The mean quantity of lactobacilli in sausages inoculated with lactobacilli rose from $8-10 \times 10^{6} / \mathrm{g}$ to over $10^{8} / \mathrm{g}$ in 3 days. Thereafter the mean lactobacillus counts remained at more than $8 \times 10^{7} / \mathrm{g}$ for the rest of the ripening time so that the mean lactobacillus level in Micrococcus + Lactobacillus sausages was less than that in Aeromonas $\mathrm{x}+$ Lactobacillus and Aeromonas $19+$ Lactobacillus sausages, the mean lactobacillus counts after 14 days of ripening being as follows: 
Table 18. Number of lactobacilli $\times 10^{6} / \mathrm{g}$ on Rogosa agar in different sausage groups.

$\begin{array}{lllllllll}\text { Sausage group } & 0 \text { days } & 1 \text { day } & 3 \text { days } & 7 \text { days } & 10 \text { days } & 14 \text { days } & 21 \text { days }\end{array}$

1. Control

number of samples .............. 18

mean

s.d.m.

0.005

0.006

2. Micrococcus + Lactobacillus

number of samples

mean

13

s.d.m

9.2

7.2

3. Aeromonas $\mathrm{x}$

number of samples

mean

$5 \quad 5$

s.d.m

0.0031

0.0053

4. Aeromonas $\mathrm{x}+$ Lactobacillus

number of samples .............. 6

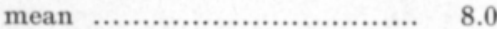

s.d.m.

8.0

8.2

\begin{tabular}{r}
\multicolumn{1}{c}{6} \\
14.7 \\
9.7
\end{tabular}

18

0.02

0.02
12

17.8

14.4
5

0.014

0.022
21

43.8

52.5
15

147.3

143.2

\section{0}

94.6

90.5

20

34.1

24.1

17

56.1

55.6

20

40.1

44.8

5

10.0

8.1

15

112.2

15

12

12

116.8

103.9

109.4

102.0

101.1

77.2

78.3

5. Aeromonas 19

number of samples ...............

mean

s.d.m.

4

$0.0073 \quad 0.037$

0.0083

0.043

6

300.0

248.9

\section{5}

44.6

5

5

5

Aeromonas $19+$ Lactobacillus

number of samples .................

mean

$6 \quad 6$

s.d.m.

10.0

6
31.2

27.6

0.037

\section{3}

9.7

7.2

6
162.7
75.7

\begin{tabular}{ccr}
6 & 6 & \multicolumn{1}{c}{6} \\
247.3 & 320.0 & 187.5 \\
162.5 & 234.8 & 95.0
\end{tabular}

s.d.m. = standard deviation of mean

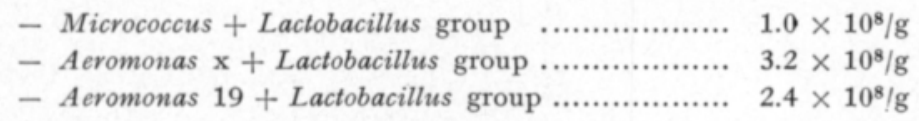

The number of lactobacilli in Aeromonas $\mathrm{x}$ and Aeromonas 19 sausages rose from $10^{3}-10^{4} / \mathrm{g}$ to a mean value of $10^{7} / \mathrm{g}$ during the first 3 days (Table 18). During the rest of the ripening the mean lactobacillus counts varied between $4 \times 10^{7} / \mathrm{g}$ and $10^{8} / \mathrm{g}$.

\section{4. 1. 3. 6. Streptococci}

The mean streptococcus counts of control sausages rose from about $10^{3} / \mathrm{g}$ to $5 \times 10^{5} / \mathrm{g}$ during the first 3 days of ripening (Fig. 14 and Table 19). Thereafter the number of streptococci rose further attaining a mean value of $2 \times$ $10^{6} / \mathrm{g}$ after 10 days of ripening. After that, the value remained in excess of $10^{6} / \mathrm{g}$.

The mean quantity of streptococci in sausages inoculated with lactobacilli and some other bacteria rose from $3 \times 10^{2}-2 \times 10^{3} / \mathrm{g}$ to values between $10^{4} / \mathrm{g}$ 
Table 19. Number of streptococci $\times 10^{4} / \mathrm{g}$ on Slanetz agar in different sausage groups.

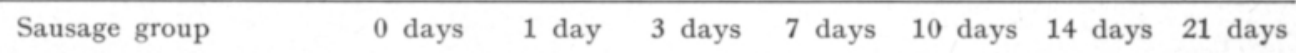

1. Control

number of samples ............... 21

mean

$21 \quad 18 \quad 19$

s.d.m.

0.091

0.21

45.0

19

$\begin{array}{ccc}20 & 21 & 20 \\ 201.5 & 166.0 & 107.0 \\ 311.0 & 235.0 & 140.0\end{array}$

2. Micrococcus + Lactobacillus

number of samples .............. 12

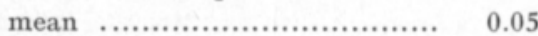

$13 \quad 13$

s.d.m.

0.04

0.13

2.3

13

13

15

14

$0.15 \quad 3.1$

5.8

1.9

3.4

2.9

3. Aeromonas $\mathrm{x}$

number of samples ................

mean ................................ 0.30

5

5

0.21

20.2

5

s.d.m.

$0.46 \quad 0.23$

14.7

133.0

5
84.6

4

5

161.8

79.9

$53.5 \quad 103.3$

$71.3 \quad 90.6$

4. Aeromonas $\mathrm{x}+$ Lactobacillus

number of samples .................

mean

$\begin{array}{lll}6 & 6 & 6\end{array}$

0.11

4.6

6

$$
6
$$

$\begin{array}{ll}4.4 & 5.7\end{array}$

$0.052 \quad 5.8$

4.7

7.7

\section{6}

4

s.d.m.

5. Aeromonas 19

number of samples

mean

3

s.d.m.

0.038

4

3

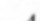

0.70

58.8

4

3

333.3

305.5

6.1

6. Aeromonas $19+$ Lactobacillus

\begin{tabular}{|c|c|c|c|c|c|c|c|}
\hline number of samples ................ & 6 & 6 & 5 & 6 & 6 & 6 & 5 \\
\hline 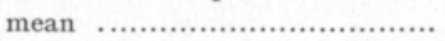 & 0.027 & 0.42 & 8.2 & 14.4 & 13.4 & 7.4 & 23.4 \\
\hline s.d.m. .................... & 0.023 & 0.37 & 7.4 & 20.9 & 21.6 & 8.0 & 33.7 \\
\hline
\end{tabular}

s.d.m. = standard deviation of mean
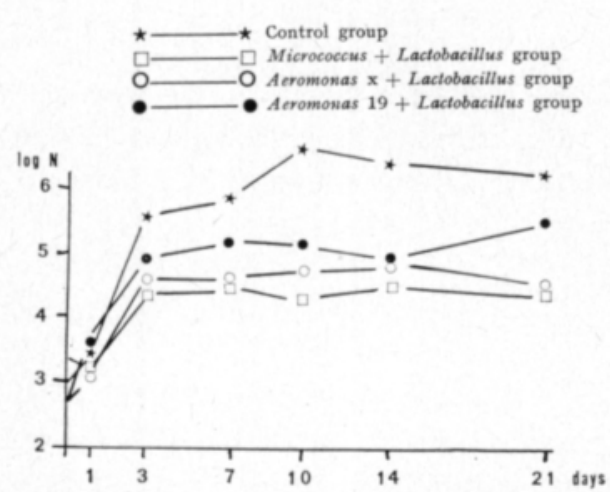

Figure 14. Number of streptococci/g on Slanetz agar in different sausage groups.

figure for the rest of the ripening time (Table 19). and $10^{5} / \mathrm{g}$ over 3 days (Fig. 14 and Table 19). Thereafter the streptococcus counts remained at a level of about $10^{4} / \mathrm{g}$ to $10^{5} / \mathrm{g}$ so that Aeromonas $19+$ Lactobacillus samples contained most and Micrococcus + Lactobacillus sausages least streptococci.

The mean streptococcus counts in Aeromonas $\mathrm{x}$ and Aeromonas 19 sausages resembled the values for control sausages, exceeding $10^{6} / \mathrm{g}$ after 7 and 10 days of ripening and the latter remaining in excess of this 
Table 20. Number of coliform bacteria $\times 10^{2} / \mathrm{g}$ on VRB agar in different sausage groups.

\begin{tabular}{|c|c|c|c|c|c|c|c|c|}
\hline & Sausage group & 0 days & 1 day & 3 days & 7 days & 10 days & 14 days & 21 days \\
\hline \multicolumn{9}{|c|}{ 1. Control } \\
\hline & number of samples ................... & 17 & 18 & 15 & 13 & 16 & 13 & 18 \\
\hline & 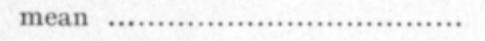 & 7.1 & 12.6 & 14.7 & 15.7 & 14.4 & 15.5 & 21.7 \\
\hline & 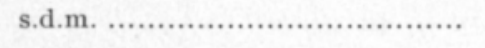 & 10.8 & 12.9 & 25.2 & 18.5 & 23.5 & 20.3 & 29.3 \\
\hline \multicolumn{9}{|c|}{ 2. Micrococcus + Lactobacillus } \\
\hline & number of samples .................. & 12 & 13 & 12 & 12 & 13 & 13 & 12 \\
\hline & 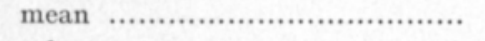 & 16.3 & 21.5 & 12.9 & 11.3 & 4.6 & 4.0 & 3.2 \\
\hline & s.d.m. ................................. & 15.8 & 24.9 & 15.2 & 21.7 & 5.9 & 8.8 & 6.8 \\
\hline \multicolumn{9}{|c|}{ 3. Aeromonas $\mathrm{x}$} \\
\hline & number of samples...$\ldots \ldots \ldots \ldots \ldots$ & 6 & 6 & 6 & 6 & 6 & 6 & 6 \\
\hline & 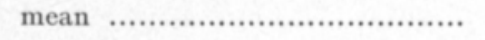 & 2.1 & 3.6 & 1.0 & 1.3 & 0.1 & 0.8 & 1.8 \\
\hline & s.d.m. .................................. & 3.1 & 4.3 & 1.4 & 1.1 & 0.2 & 0.8 & 1.8 \\
\hline \multicolumn{9}{|c|}{ 4. Aeromonas $\mathrm{x}+$ Lactobacillus } \\
\hline & number of samples .................... & 6 & 6 & 6 & 6 & 6 & 6 & 6 \\
\hline & 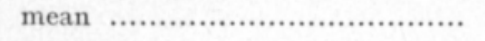 & 1.6 & 1.2 & 2.0 & 0.9 & 1.0 & 0.6 & 0.7 \\
\hline & 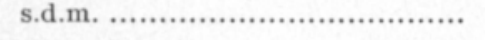 & 1.3 & 1.5 & 2.6 & 1.2 & 0.6 & 0.7 & 0.6 \\
\hline \multicolumn{9}{|c|}{ 5. Aeromonas 19} \\
\hline & number of samples $. . . \ldots \ldots \ldots \ldots \ldots . . . .$. & 4 & 4 & 4 & 4 & 4 & 4 & 4 \\
\hline & 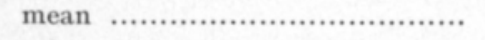 & 0.6 & 9.3 & 15.6 & 5.3 & 3.8 & 4.4 & 4.7 \\
\hline & s.d.m. .................................. & 0.5 & 15.3 & 18.7 & 5.1 & 5.5 & 4.0 & 6.4 \\
\hline \multicolumn{9}{|c|}{ 6. Aeromonas $19+$ Lactobacillus } \\
\hline & number of samples ................... & 6 & 6 & 6 & 6 & 6 & 5 & 4 \\
\hline & 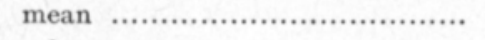 & 1.0 & 3.6 & 6.3 & 5.3 & 3.8 & 4.1 & 4.2 \\
\hline & s.d.m. ................................... & 1.2 & 3.4 & 6.8 & 4.9 & 5.1 & 3.9 & 6.2 \\
\hline
\end{tabular}

s.d.m. = standard deviation of mean

\section{4. 1. 3. 7. Coliform bacteria}

The mean quantity of coliform bacteria in control sausages rose from $7 \times$ $10^{2} / \mathrm{g}$ to a little over $10^{3} / \mathrm{g}$ and stayed at this level for the rest of the ripening time (Fig. 15 and Table 20). The mean level of coliform bacteria in Micrococcus + Lactobacillus sausages, on the other hand, decreased from $2.0 \times 10^{3} / \mathrm{g}$ to less than $10^{3} / \mathrm{g}$ after 10 days of ripening and remained at less than $10^{3} / \mathrm{g}$ for the rest of the ripening time.

The mean quantity of coliform bacteria in Aeromonas $\mathrm{x}+$ Lactobacillus

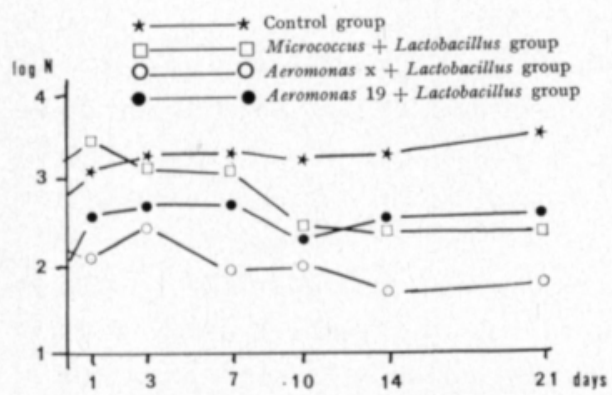

Figure 15. Number of coliform bacteria/g on VRB agar in different sausage groups. sausages decreased from just over $10^{2} / \mathrm{g}$ to less than $10^{2} / \mathrm{g}$ after 10 days of ripening (Fig. 15 and Table 20). The corresponding number of bacteria in Aeromonas $19+$ Lactobacillus sausages ranged between $10^{2} / \mathrm{g}$ and $10^{3} / \mathrm{g}$. The mean quantity of coliform bacteria in Aeromonas $\mathrm{x}$ and Aeromonas 19 sausages ranged between $10^{2} / g$ and $10^{3} / \mathrm{g}$ throughout ripening (Table 20). The highest values appeared after one day or 3 days of ripening. 


\subsubsection{USE OF VIBRIO COSTICOLUS AS A STARTER CULTURE}

The effect of Vibrio costicolus on the quality of dry sausage was studied. The strain was isolated from curing brine and improves the quality of dried hams (РетÄJä 1972, РetäJä et al. 1973).

$V$. costicolus did not thrive in dry sausage. The amount of $V$. costicolus fell noticeably during the first 3 days of ripening from $10^{7} / \mathrm{g}$ to about $10^{3} / \mathrm{g}$. In 7 day old sausages no $V$. costicolus was found. As ripening began $V$. costicolus reduced nitrate, producing $20-30 \mathrm{ppm}$ nitrite in the first 3 days of ripening thereby securing colour formation. This nitrate reduction did not happen regularly in every experimental series. When lactobacilli were inoculated along with $V$. costicolus the colour formation was missing because vibrios disappeared and the lactobacilli therefore produced discolourations. The consistency of these sausages was firm. On the basis of these observations, especially that of the disappearance of $V$. costicolus from dry sausage, it can be concluded that $V$. costicolus cannot be used as a starter culture for dry sausage.

\section{4. 3. USE OF ACHROMOBACTER STRAINS AS A STARTER CULTURE}

The effect of Achromobacter 22, Achromobacter guttatus and Achromobacter $X$ strains on the quality of dry sausage was studied. The first strain was isolated from curing brine (РетÄJÄ et al. 1973), strain X from a control dry sausage in this research and $A$. guttatus had been received from Nora Winterhalter of Eidgenossische Technische Hochschule, Zürich, Switzerland.

Achromobacter 22 failed to thrive in dry sausage. It disappeared completely after one week. Clearly then, it did not have any marked effect on the quality of dry sausage. The sausages inoculated with it alone were in the same class as control sausages and those inoculated with Achromobacter 22 and lactobacilli had better consistency than the control. Two experimental series were carried out.

The Achromobacter guttatus strain also failed to grow in dry sausage and disappeared even more quickly than Achromobacter 22. It had no effect on the quality of dry sausage. Only one series of experiments was carried out.

Dry sausages were inoculated with Achromobacter X alone and with lactobacilli in three experimental series. In one series the inoculum was successful. Achromobacter $\mathrm{X}$ thrived in dry sausage, the number of cells being about $2 \times$ $10^{7} / \mathrm{g}$ after 7 days of ripening after which it fell. The effect of the Achromobacter strain used when inoculated with lactobacilli was the same as that of micrococci: the colour was red, consistency firm and aroma and flavour good. When inoculated with just Achromobacter $\mathrm{X}$ the colour of the sausages was good but the consistency, aroma and flavour were in the same class as control sausages.

In two other experimental series Achromobacter $\mathrm{X}$ not only failed to thrive but disappeared during the first 3 days of ripening. Neither did this strain survive very well after lyophilization. It can be concluded then, that none of the Achromobacter strains used is suitable for use as a starter culture in dry sausage. 


\section{4. 4. USE OF ESCHERICHIA COLI AS A STARTER CULTURE}

Escherichia coli was selected as a standard enterobacter for an experimental starter culture. Three experimental series contained sausages inoculated with $E$. coli alone and with $E$. coli and lactobacilli. The sausages inoculated with $E$. coli alone were in the same quality class as control sausages. However, the quality of $E$. coli + Lactobacillus sausages was clearly better though not as good as that of either Aeromonas x or $19+$ Lactobacillus or Micrococcus + Lactobacillus sausages. The colour was not as clear, consistency not as firm and aroma and flavour not as palatable as in these latter samples.

The $\mathrm{pH}$ value of sausages inoculated with $E$. coli alone was quite high (5.40). The $\mathrm{pH}$ values of $E$. coli + Lactobacillus sausages were between 5.0 and 5.10 . E. coli reduced nitrate quite strongly, producing a mean nitrite content after 3 days of ripening of $48 \mathrm{ppm}$ in E. coli sausages and $44 \mathrm{ppm}$ in E. coli + Lactobacillus sausages. The number of $E$. coli in sausages inoculated with $E$. coli alone and E. coli + Lactobacillus decreased during ripening from $10^{6}-10^{7} / \mathrm{g}$ to $10^{5}-10^{6} / \mathrm{g}$.

\section{4. 5. USE OF PROTEUS VULGARIS AS A STARTER CULTURE}

Proteus vulgaris was inoculated alone and with lactobacilli into dry sausage in three experimental series to investigate how this kind of strongly proteolytic and spoiling bacteria grows in dry sausage and affects its properties. When dry sausages were inoculated with $P$. vulgaris alone, the bacteria had an adverse effect on the quality of the sausages. The consistency did not develop. Instead, colour was produced, which is natural since $P$. vulgaris is a strong nitrate reducer. As a rule, however, the colour faded in the later stages cf ripening. The aroma and flavour of $P$. vulgaris sausages were unpalatable.

When $P$. vulgaris was inoculated together with lactobacilli into dry sausage the consistency of the sausage was only slightly better than without lactobacilli. The colour did not develop in $P$. vulgaris + Lactobacillus sausages and the aroma and flavour were unsatisfactory.

The $\mathrm{pH}$ value of $P$. vulgaris sausages decreased, as in the control sausages. The $\mathrm{pH}$ value of $P$. vulgaris + Lactobacillus sausages decreased, as in the sausages inoculated with micrococci and labtobacilli as a rule. However, in an experimental series of sausages containing more than $10^{7}$ Proteus cells $/ g$ the $\mathrm{pH}$ value remained above 5,35 throughout ripening.

The number of Proteus cells changed considerably. In one experimental series there were more than $10^{7}$ cells/g throughout ripening while in two other series the number decreased from a level of $3 \times 10^{\mathrm{s}} / \mathrm{g}$ and $P$. vulgaris bacteria practically disappeared after $3-7$ days of ripening. 


\section{Discussion}

\section{1. Effect of bacterial inoculations on the ripening of dry sausage}

It is accepted that the use of bacterial cultures improves the quality of dry sausage. Since the Pediococcus cerevisiae starter culture developed by Niven et al. (1955) and the Micrococcus starter culture developed by NinivaAra (1955), many new starter cultures have been developed: different Lactacel and Saga products in the USA, French and Spanish starter cultures, and starters in Bulgaria, the Soviet Union, Yugoslavia, the GDR etc. Perhaps the most important of these is the mixed culture of micrococci and lactobacilli developed by NuRmi $(1966)$. Also, according to Liepe $(1971,1975,1976)$ the use of lactobacilli and micrococci is necessary to assure the controlled ripening of diy sausage. In Nurmi's method lactobacilli produce the lactic acid necessary for the development of the consistency and aroma of dry sausage. Micrococci reduce nitrate to nitrite and avoid the discolourations which lactobacilli would produce. This method also considerably reduces the processing time. This mixed starter culture of micrococci and lactobacilli is used in Europe in particular, but in other countries, too. In addition to "Duploferment 66" developed on the basis of the studies of Nurmi, there are some other commercial products which contain micrococci and lactobacilli (Saga III).

The Micrococcus + Lactobacillus starter culture is also the reference with which other experimental sausages are compared in this investigation. Like the bacteria of this starter culture, all cultures used in dry sausage have in practice been gram-positive. The effect of gram-negative bacteria on the aroma and flavour of dry sausage has been studied most notably by KoHNLE (1953), Keller (1954), Keller and Meyer (1954), Meyer (1954), Losem (1956) and ECKERT (1958). The purpose of this examination was to investigate the possible use of gram-negative bacteria in dry sausage.

The effect of the following gram-negative bacteria on the quality of dry sausage was studied by inoculating the bacteria alone and with Lactobacillus plantarum (NURMi 1965, 1966): two Aeromonas strains, Vibrio costicolus, three Achromobacter strains, Escherichia coli and Proteus vulgaris.

\section{Aeromonas st rain s $\mathrm{x}$ and 19}

According to Buttiaux (1959) Aeromonas bacteria play an important part in the biological process on which the manufacture of raw sausage is based. When Aeromonas strains $\mathrm{x}$ and 19 were inoculated alone their favourable effect on the quality of dry sausage was restricted to improving colour due to the nitrate-reducing capacity of the Aeromonas strains. When inoculated along with lactobacilli, both Aeromonas x and Aeromonas 19 improved the ripening of dry sausage. The colour developed over 3 days and was at least as good as that of Micrococcus + Lactobacillus sausages throughout the ripening period.

The $\mathrm{pH}$ value of sausages with Aeromonas x or $19+$ Lactobacillus inoculations decreased as quickly as in Micrococcus + Lactobacillus sausages and often 
even more quickly. The $\mathrm{pH}$ values, too, are as low or a little lower than in Micrococcus + Lactobacillus sausages. According to Nurmi (1965) the inoculation of lactobacilli caused a rapid decrease of the $\mathrm{pH}$ value of dry sausage. Concurrently the desired consistency also developed rapidly. Also, the consistency scores of sausages inoculated with Micrococcus + Lactobacillus, Aeromonas $\mathrm{x}+$ Lactobacillus or Aeromonas $19+$ Lactobacillus were best. The last of these, however, was better (significance level 0.05) than that of Micrococcus + Lactobacillus samples and better (significance level 0.001) than that of Aeromonas x + Lactobacillus samples. Results from samples of different ages were taken into account for this comparison. The consistency, measured mechanically, was more often firmer in Aeromonas + Lactobacillus sausages than in Micrococcus + Lactobacillus sausages. However, the values obtained did not differ very much from each other.

The aroma of sausages inoculated with the Aeromonas 19 strain and lactobacilli was better (significance level 0.001 ) than the aroma of sausages inoculated with micrococci and lactobacilli. There were no statistical differences between Micrococcus + Lactobacillus and Aeromonas $\mathrm{x}+$ Lactobacillus samples. The flavour of Aeromonas $\mathrm{x}+$ Lactobacillus (significance level 0.05) and Aeromonas $19+$ Lactobacillus (significance level 0.001) sausages was significantly better than the flavour of Micrococcus + Lactobacillus sausages. The flavour of all the sausages mentioned was certainly better than in the other sausage groups. NuRmi (1965) observed that micrococci and lactobacilli improved the flavour of dry sausage. The Aeromonas + Lactobacillus inoculations used have proved to have an even more beneficial effect on the flavour. The scores of the evaluations of the sausages of different ages were processed together using the t-test when the aroma and flavour of different sausage groups were compared.

There were no significant differences between the evaluations of different panel members with respect to each property or with respect to the products. Products of different ages were tested separately.

Nitrate was strongly reduced by Micrococcus and Aeromonas strains, the nitrite level ranging from 10 to $100 \mathrm{ppm}$ after 3 days of ripening. After 3 days the nitrite content was lower in sausages inoculated with lactobacilli because of the low $\mathrm{pH}$ value. Many countries have discussed banning the use of nitrate. Puolanne (1977) concluded that it is safe from the point of view of technology to manufacture dry sausage using $150 \mathrm{ppm} \mathrm{KNO}_{3}$ or $100 \mathrm{ppm} \mathrm{NaNO}_{2}$ or $50 \mathrm{ppm} \mathrm{NaNO}_{2}$ and 75 ppm $\mathrm{KNO}_{3}$ when starter culture is used. LeISTNER et al. (1973) state that gram-negative bacteria do not resist sodium nitrite. The count of enterobacteria in 12 day old brine $(11 \% \mathrm{NaCl})$ is $10^{5} / \mathrm{ml}$ but only $10^{2} / \mathrm{ml}$ when $0.06 \%$ nitrite is used. In some experimental series of this investigation the effect of nitrite on Aeromonas strains in dry sausage has also been examined. Sausages were prepared using nitrite and Aeromonas $\mathrm{x}+$ Lactobacillus and Aeromonas $19+$ Lactobacillus inoculations. According to the results nitrite does not disturb the growth or prevent the Aeromonas strains used from thriving.

Based on the weight losses, the following calculations can be made. If control sausages ripen in 3 weeks with a mean weight loss of $24.6 \%$ and the Micro- 
coccus + Lactobacillus and Aeromonas x or $19+$ Lactobacillus sausages ripen in 10 days with a mean weight loss of about $18.3 \%$ this represents a saving in weight loss of $6 \%$ units. Nurm (1966) found that sausages with Micrococcus + Lactobacillus inoculation ripened in just 6-7 days with a weight loss of $10 \%$. In this study too, the sausages often ripened in one week but were not fit for sale before they had ripened for 10 days.

\section{Vibrio costicolus a n A Achromobacter st $\mathrm{r}$ a in s}

Neither the Vibrio costicolus strain nor the Achromobacter strains thrived in dry sausage and both disappeared during the first few days of ripening. This means that their effect on the ripening of dry sausage is very small, both alone and when inoculated together with lactobacilli.

\section{Escherichia coli}

Escherichia coli did not have a very beneficial effect on the ripening of dry sausage when inoculated alone. When inoculated with lactobacilli its effect on the quality of the sausage very much resembled that of micrococci inoculated with lactobacilli. However, the colour, consistency and flavour were not as good.

\section{Proteus vulgaris}

Inoculation with Proteus vulgaris was used to establish how this kind of strongly proteolytic organism affects dry sausage. The results show that it is harmful even when inoculated with lactobacilli. The consistency, colour, aroma and flavour were not acceptable.

\section{2. Effect of bacterial inoculations on bacterial flora of dry sausage}

According to Nurmi (1966) Lactobacillus inoculation is necessary to reduce the $\mathrm{pH}$ value and so to develop the consistency of dry sausage. The lactobacilli alone produced discolourations because they form hydrogen peroxide and little or no catalase to decompose hydrogen peroxide. Therefore bacteria which are catalase positive and which reduce nitrate are needed besides lactobacilli to prevent discolourations and to produce a good colour.

NinnivaARa (1955) had developed a method in which micrococci were used as starter culture in dry sausage. So Nurmi used micrococci to prevent discolourations. In this research two gram-negative Aeromonas strains were used instead of micrococci and good quality sausages resulted. NURMi (1966) stated that micrococci have a strongly depressing effect on the number of lactobacilli in dry sausage - the number of lactobacilli is smaller when inoculated together with micrococci. In this investigation the number of lactobacilli was often significantly higher when inoculated with Aeromonas x or 19 than when inoculated with micrococci (Table 21). This property of Aeromonas strains proved favourable. It was stated earlier that most Aeromonas + Lactobacillus sausages were better than Micrococcus + Lactobacillus samples in colour, con- 
Table 21. Comparison of lactobacillus counts of Micrococcus + Lactobacillus sausages with those of Aeromonas x + Lactobacillus and Aeromonas $19+$ Lactobacillus sausages.

$++=$ more lactobacilli than in Micrococcus + Lactobacillus sausages, significance level $<0.01$

$+=, \quad, \quad, \quad$,,$<0.05$

$-\quad=$ no significant difference

0 days 1 day 3 days 7 days 10 days 14 days 21 days

$\begin{array}{lllllll}- & + & - & - & + & + & - \\ - & - & - & + & + & + & ++\end{array}$

sistency, aroma and flavour. Since Aeromonas strains allowed higher lactobacillus levels in sausage, more acid was formed and so the consistency was firmer and the colour brighter. Aeromonas strains perhaps improve the aroma and flavour, although this may be due to the higher number of lactobacilli.

Aldeary Nurmi (1966) observed that Lactobacillus inoculum prevents the growth of streptococci and coliforms. The same phenomenon was found in this investigation. Also Aeromonas inoculations alone restrained these bacteria from thriving in dry sausage.

Lerche (1956 a, 1956 b), Ten Cate (1960) and Szczepaniak and Pezacki (1974) have stated that gram-negative bacteria disappear from dry sausage during the first few days. NinivaAra and PoHJA (1956) found that the number of gram-negative bacteria decreased during the smoking period. NURMI (1966) also observed that the proportion of gram-negative bacteria in microbial flora was very low. However, when he inoculated gram-negative bacteria into dry sausage the number of these bacteria remained rather high during the first week of ripening. In this study it was observed that the Vibrio costicolus and Achromobacter strains used disappeared from dry sausage during the first week. Escherichia coli and Proteus vulgaris on the other hand diminished more slowly but never disappeared completely from the sausage.

From what has been said in the previous chapter it can be concluded that as a rule gram-negative bacteria do not thrive or grow well in dry sausage. However, in the present study Aeromonas x and Aeromonas 19 strains which did thrive and grow in dry sausage were found. Further, since both Aeromonas strains reduce nitrate, are catalase positive and improve the aroma and flavour of dry sausage, they can be recommended for use as starter cultures for dry sausage. Aeromonas $\mathrm{x}$ and 19 strains are easy to cultivate, survive well after freezing or lyophilization and are apathogenic.

\section{Summary and conclusion}

The possible use of gram-negative bacteria as starter cultures for dry sausage was studied by inoculating the following gram-negative bacteria into dry sausage both alone and with Lactobacillus plantarum: Aeromonas x, Aeromonas 
19, Vibrio costicolus, Achromobacter 22, Achromobacter guttatus, Achromobacter $X$, Escherichia coli or Proteus vulgaris. Sausages without any inoculation and sausages inoculated with micrococci and lactobacilli were used as references in the examination. Twenty-two series of dry sausage experiments were carried out and examined over a ripening period of 21 days. The following conclusions can be drawn concerning the effect of bacterial inoculations on the ripening process and the quality of dry sausage:

1. The colour, consistency, aroma and flavour of the samples without inoculum were worst as a rule, Micrococcus + Lactobacillus sausages being much better and competing in quality with other sausages. The good colour of sausages inoculated with micrococci and lactobacilli developed in 3 days and the firm consistency in 7 days. The aroma and flavour were also acceptable. Micrococci reduced nitrate in 3 days so that the mean nitrite content reached $34.1 \mathrm{ppm}$ and thereafter decreased. The number of micrococci was a little over $10^{7} / \mathrm{g}$ throughout ripening while the number of lactobacilli rose from about $10^{7} / \mathrm{g}$ to $10^{8} / \mathrm{g}$ in 3 days. The $\mathrm{pH}$ value decreased in 3 days from 5,70 to 5,28 .

2. Aeromonas $\mathrm{x}$ and 19 strains had a favourable effect on the colour of dry sausage but otherwise the quality of the samples was very similar to that of the control sausages. Aeromonas strains did not form observable amounts of acid in dry sausage and so did not improve the consistency. The aroma and flavour were better than in the control sausages.

3. Aeromonas $\mathrm{x}$ and $\mathbf{1 9}$ strains had a very favourable effect on the quality of dry sausage when inoculated together with lactobacilli. Both strains reduced nitrate, the colour forming during the first 3 days. The $\mathrm{pH}$ value of Aeromonas + Lactobacillus sausages decreased even more quickly and to a lower value than in Micrococcus + Lactobacillus sausages, being about 5.20 after 3 days of ripening. The consistency of Aeromonas + Lactobacillus samples developed within one week and was at least as good as and often firmer than in Micrococcus + Lactobacillus sausages. The consistency of Aeromonas $19+$ Lactobacillus sausages was better at the 0.05 significance level than that of Micrococcus + Lactobacillus samples. The aroma and flavour of Aeromonas + Lactobacillus sausages were as good as or better than those of Micrococcus + Lactobacillus sausages. The aroma and flavour of Aeromonas $19+$ Lactobacillus sausages were significantly better (significance level 0.001) than Micrococcus + Lactobacillus sausages. The flavour of Aeromonas $\mathrm{x}+$ Lactobacillus sausages was better at the 0.05 level than Micrococcus + Lactobacillus sausages.

The number of bacteria, roughly the number of lactobacilli, was often significantly higher in Aeromonas + Lactobacillus sausages, (range $2-4 \times 10^{8} / \mathrm{g}$ between 3 and 21 days of ripening) than in Micrococcus + Lactobacillus sausages (range $8 \times 10^{7}-1.5 \times 10^{8} / \mathrm{g}$ between 3 and 21 days of ripening). For this reason the former sausages ripened more quickly than the latter. 
4. Vibrio 21 and three Achromobacter strains not only failed to thrive in dry sausage, but disappeared completely during the first 7 days of ripening. The sausages inoculated with Escherichia coli alone were in the same quality class as the control sausages. When inoculated with lactobacilli, E. coli had very much the same effect as micrococci. However, Micrococcus + Lactobacillus sausages were slightly better in every respect than E. coli + Lactobacillus sausages. Proteus vulgaris had adverse effects when inoculated into dry sausage both alone and even with lactobacilli.

\section{Conclusion}

The investigation has proved that gram-negative bacterial strains Aeromonas $\mathrm{x}$ and 19 inoculated with lactobacilli improve the quality of dry sausage and that, especially with the Aeromonas $19+$ Lactobacillus inoculum, better diy sausage was obtained than with micrococci and lactobacilli.

\section{REFERENCES}

BaldeniUs, S. 1954. Untersuchungen über den Einfluss von Temperatur und Kochsalz auf den Bakteriengehalt der Rohwurst. Diss. Veter. Med. Fak. Justus Liebig Hochsch. Giessen. 48 p.

Bergey's Manual of Determinative Bacteriology 1957. 7th Ed. by Breed, R. S., Murray, E. G. D. and Smith, N. R. The Williams \& Wilkins Co., Baltimore, Md.

Bergey's Manual of Determinative Bacteriology 1974. 8th Ed. by Buchanan, R. E. \& Gibbons, N. E. The Williams \& Wilkins Co., Baltimore, Md.

Butriaux, R. 1957. Technique simple d'examens bacteriologique des saumures de jambon et ses resultats. In "The Microbiology of Fish and Meat Curing Brines. Proc. II. Int. Symp. Food Microbiology: 137-146. Her Majesty's Stationary Office, London.

- - 1959. The value of association Escherichiae - group D streptococci in the diagnosis of contamination in foods. J. Appl. Bacteriol. 22: 153-158.

Caselitz, F-H. 1965. Pseudomonas-Aeromonas und ihre human medizinische Bedeutung. Veb Gustav Fischer Verlag, Jena, 1966.

Coretri, K. 1956 a. Veränderungen des Keimgehaltes während der Reifung von Rohwurst. Fleischwirtschaft 8:197-199.

- -1956 b. Rohwurstkeime und Wurstreifung. Fleischwirtschaft 8: 260-261.

- - 1958. Die Bakterienflora fehlerhafter Rohwürste. Arch. Lebensmittelhyg. 9: 32 - 35.

- 1977. Starterkulturen in der Fleischwirtschaft. Fleischwirtschaft $57: 386-390,393-394$.

DAhle, H. K. \& NordstogA, K. 1968. Identification of aeromonads in furred animals. Acta vet. scand. 1968, 9:65-70.

Deirel, R. H. 1974. Technology of fermented semi-dried and dried sausages. Proc. Meat Ind. Res. Conf. 1974: 57-60.

- - , Nrven, C. F., Jr. \& Wrison, G. D. 1961 a. Microbiology of meat curing III. Some microbiological and related technological aspects in the manufacture of fermented sausages. Appl. Microbiol. 9: 156-161.

- - , Wilson, G. D. \& Nrven, C. F., Jr. 1961 b. Microbiology of meat curing IV. A lyophilized Pediococcus cerevisiae starter culture for fermented sausage. Appl. Microbiol. 9: $239-243$. 
Djedjeva, G. 1973. Personal communication.

Djevizov, St. 1973. Application industrielle de cultures starters sons forme de souches en solution lors de la fabrication de sancissons secs Bulgares. XIX Reunion Européenne des Chercheurs en Viande: 1645-1654. Paris.

EскERT, M. 1958. Versuche über die bakterielle Beeinflussung von Reifung und Aromatisierung bei Rohwürsten. Diss. Veter. Med. Fak. Justus Liebig Univ. Giessen. 60 p.

Edwards, P. R. \& Ewing, W. H. 1972. Identification of Enterobacteriaceae. Third Edition. Burgess Publishing Company, Minneapolis, Minnesota.

Erikson, B. 1961. The microflora of Swedish dry sausage. Nord. Veter. Med. 13: 333-340.

Everson, C. N., Danner, W. E. \& Hammes, P. A. 1970. Improved starter culture for semi-dry sausage. Food Technology 24: 42-44.

Fiszer, W. 1970. Die Dynamik der Rohwurstgärung. Fleischwirtschaft 50:325-328.

Gorbatov, V. M., Mikhailova, A. E., Maroushkina, V. I., Mikhailova, M. M. \& Loudanova, N. V. 1974. A study into the influence of useful-commercial strains upon biochemical and organoleptical qualities of canned ham "Vetchina" produced according to an accelerated technology. Proc. XX Eur. Meeting of Meat Res. Workers: 108-110. Dublin.

Hawthorn, J. \& Leitch, J. M. 1962. Recent Advances in Food Science, volume 2, Butterworths, London.

Hugh, R. \& Leifson, E. 1953. The taxonomic significance of fermentative versus oxidative metabolism of carbohydrate by various gram-negative bacteria. J. bact. $66: 24-27$.

INAL, T. 1969. Versuche zur Qualitätsverbesserung der türkischen Rohwurst durch Zusatz von Mikrokokken- und Pediokokkenstämmen. Fleischwirtschaft 49: 487-493.

Jawetz, E., Melnick, J. L. \& Adelberg, A. 1968. Medizinische Microbiologie. Springer Verlag, Berlin, Heidelberg, New York.

Jensen, L. B. \& PADdock, L. 1940. Sausage treatment with lactobacilli, U. S. Patent 2, $225,783$.

Казвонм, Н. 1954. Bakteriologische Untersuchungen von Salami und Cervelatwurst. Diss. Veter. Med. Fak. Freien Univ. Berlin. 83 p.

Keller, H. 1954. Die Bakterielle Aromatisierung der Rohwurst. Fleischwirtschaft 6: 125-126.

- $-\&$ MEYer, E. 1954. Bakterielle Aromatisierung der Rohwurst. Fleischwirtschaft 6: $453-454$.

KoHnLE, K. 1953. Untersuchungen über aromabildende und halophile Bakterien in der Rohwurst. Diss. Veter. Med. Fak. Justus Liebig Hochsch. Giessen. 43 p.

Kucharkova, L. L., Lawrowa, L. P., Freudlin, E. M., Perowa, P. W. \& Krylowa, W. W. 1963. Untersuchung der Anvendung von Bakterienkulturen in der Rohwurstherstellung. Ber. IX Europäischer Kongress der Fleischforscher. 24 p. Budapest.

Kuchling, E. 1963. Zur Frage der Verwendung von Starterkulturen bei der Herstellung von Rohwurst. Ber. IX Europäischer Kongress der Fleischforscher. 19 p. Budapest.

Leistner, L. 1960. Microbiology of Ham Curing. 12th Conf. Amer. Meat Inst. Found. Proc., Circ. 61: 17-23.

,- 1963 . Rohwurst in den USA. Arch. Lebensmittelhyg. 14:62-64.

- - , Hechelmann, H. \& Uchida, K. 1973. Welche Konsequenzen hätte ein Verbot oder eine Reduzierung des Zusatzes von Nitrat und Nitritpökelsalz zu Fleischerzeugnissen. Fleischwirtschaft 53:371-378.

LERCHE, M. 1956 a. Laktobazillen in schnittfester Rohwurst. Arch. Lebensmittelhyg. $7: 1-4$.

- 1956 b. Mikroben in Rohwurst. Berl. Münch. tierärztl. Wschr. 69:91-93.

- - 1957. Mikrobiotische Vorgänge bei der Rohwurstreifung. Berl. Münch. tierärztl. Wschr. 70: $13-16$.

Liepe, H.-U. 1971. Die Kontrollierte Fermentation von Rohwurst. Neue Fleischer Zeitung Nr. $16,19,22 / 1971$.

- - 1975. Die Rohwurst- ein Fermentationsprodukt. Fleischerei 1975. 3: 31-32.

- - 1976. Die praktische Anvendung von Starterkulturen bei Rohwurst. Fleischwirtschaft 56:178, 180-183.

Losem, P. 1956. Versuche zur Verbesserung von Dauerwurst durch Aromabakterien. Diss. Veter. Med. Fak. Justus Liebig Hochsch. Giessen. 71 p.

Man, J. C. de, Rogosa, M. \& Sharpe, M. E. 1960. A medium for the cultivation of lactobacilli. J. Appl. Bact. 23: 130-135. 
MEYer, E. 1954. Versuche zur bakteriellen Aromatisierung von Rohwürsten. Diss. Veter. Med. Fak. Justus Liebig Hochsch. Giessen. 40 p.

Mintzlaff, H.-J. \& Leistner, L. 1972. Schimmelpilze als Starterkulturen bei der Rohwurstherstellung. Ber. Starterkultur Symposium: 45-67. Institut für Fleischtechnologie, Universität Helsinki.

Mäkel.̈, P. H. 1975. Personal communication.

- - \& MAYer, H. 1976. Enterobacterial common antigen. Bact. Rev. 40: 591-632.

Möller, M. 1955. Der Keimgehalt des Rohwurstbrätes. Diss. Veter. Med. Fak. Freien Univ. Berlin. 43 p.

NintvanRA, F. P. 1955. Uber den Einfluss von Bakterienreinkulturen auf die Reifung und Umrötung der Rohwurst. Acta Agr. Fenn. 84: 1-128.

- 1958. Observations on the significance of a Micrococcus-strain in meat processing. Proc. II. Int. Symp. Food Microbiology: 187-189. London.

- $-\&$ Ронј A, M. S. 1956. Úber die Reifung der Rohwurst. I. Mitt. Die Veränderung der Bakterienflora während der Reifung. Z. Lebensm. Unters.-Forsch. 104: 413-422.

— - \& РонјА, M. S. 1957 a. Über die Reifung der Rohwurst. II. Mitt. Die Beschreibung der aus Rohwurst isolierten Bakterienstämme und ihre bedeutung beim Reifungsprozess. Z. Lebensm. Unters.-Forsch. 106: 187-196.

_ - \& Ронј А, M. S. 1957 b. Die in der Rohwurst vorkommenden Bakterien und ihre bedeutung beim Reifungsprozess. Fleischwirtschaft 9:264-268.

- - \& РонјА, M. S. 1957 c. Erfahrungen über die Herstellungen von Rohwurst mittels einer Bakterienreinkultur. Fleischwirtschaft 9: 789-790.

Niven, C. F., Jr. 1952 a. Significance of the lactic acid bacteria in the meat industry. Proc. 4th Res. Conf. Council Res., Amer. Meat Inst. 31-37.

-1952 b. Symposium of the lactic acid bacteria. Part IV. Industrial significance of the lactic acid bacteria. Bact. Rev. 16: 247-260.

- - , Deibel, R. H. \& Wilson, G. D. 1955. The use of pure culture starters in the manufacture of summer sausage. Ann. Meeting Amer. Meat Inst. 5 p.

- - , Deibel, R. H. \& Wilson, G. D. 1958. The AMIF sausage starter culture. Amer. Meat Inst. Found. Circ. no. 41 Jan. 25 p.

Nurmi, E. 1965. The effect of lactobacilli and micrococci cultures on the ripening of dry sausage. Proc. XI Eur. Meeting of Meat Res. Workers. 24 p. Beograd.

- - 1966. Effect of bacterial inoculations on characteristics and microbial flora of dry sausage. Acta Agr. Fenn. 108: 1-77.

PeräJÄ, E. 1972. Starterkulturen bei der Pökelung. Ber. Starterkultur Symposium: 165-179. Institut für Fleischtechnologie, Universität Helsinki.

- - 1977. Untersuchungen über die Verwendungsmöglichkeiten von Starterkulturen bei Brühwurst. Fleischwirtschaft 57: 109-112.

- - , Laine, J. \& Ninnivaara, F. P. 1973. Einfluss der Pökellakebakterien auf die Eigenschaften gepökelten Fleisches. Fleischwirtschaft 53:680-682, 685-686.

PouJA, M. S. 196C. Menetelmä mikrokokkikantojen tutkimukseksi eräiden lihajalosteiden valmistusta silmälläpitäen. Lisensiaattityö. (A selection procedure for examination of micrococci with a view to the manufacturing of certain meat products) Licentiate thesis Inst. Microbiol. Univ. Helsinki. 103 p.

РонJA, M. S. \& Ninnivana, F. P. 1957. Úber die Reifung der Rohwurst. III. Mitt. Über die antagonistische Wirkung eines Mikrokokkenstammes gegen die in Rohwurst vorkommenden Bakterienstämme. Z. Lebensm. Unters.-Forsch. 106: 298-301.

- $-\&$ NinnivaAra, F. P. 1960. Die Bedeutung einiger stark proteolytischer, zur Gattung Bacillus gehöriger Stämme bei der Reifung der Rohwurst. Fleischwirtschaft 12: 932-934.

Puolanne, E. 1977. Der Einfluss von verringerten Nitrit- und Nitratzusätzen auf die Eigenschaften der Rohwurst. J. Scient. Agric. Soc. Finland 49:1-106.

Reuter, G. 1970. Lactobazillen und eng verwandte Mikroorganismen in Fleisch und Fleischerzeugnissen. Fleischwirtschaft 50: 951-962.

- - 1972. Versuche zur Rohwurstreifung mit Laktobazillen- und Mikrokokken-starterkulturen. Fleischwirtschaft 52: $465-473$. 
- - , Langner, H. J. \& Sinell, H. J. 1968. Entwicklung der Mikroflora in schnellreifender deutcher Rohwurst und analoge quantitative Aminosäureanalyse bei einer Salami. Fleischwirtschaft 48: 170-176.

Rogosa, M., Mitchell, J. A. \& Wiseman, R. F. 1951. A selective medium for the isolation and enumeration of oral and fecal lactobacilli. J. Bact. 62: 132-133.

Rozier, J. 1970. Etude de l'activite catalasique des viandes de porc et de boeauf. XVI Reunion Europe'enne des Cherheurs en Viande, Tome 1: 561-568. Varna.

SснӧNBERG, F. 1953. Die Ursachen von Fehlfabrikaten bei Rohwurstsorten unter besonderer Berücksichtigung der Trocknungsfehler. Fleischwirtschaft 5: 155-157.

- $-\&$ War.z, E. 1954. Der Einfluss von Temperatur und Kochsalz auf die Bazillen der Mesentericus-Subtilis Gruppe und seine Beziehung zur Entstehung der Beissigkeit und Kernfäulnis bei den Rohwurstsorten. Fleischwirtschaft 6: 33-35.

Sнан, R. B. 1977. Personal communication.

Slanetz, L. W. \& Bartley, C. H. 1957. Numbers of enterococci in water, sewage and faces determined by the membrane filter technique with an improved medium. J. Bact. 74: $591-595$.

Stoya, W. 1969. Vereinfache Nitratbestimmung in Lebensmitteln, insbesondere in Fleischwaren. Deutsche Lebensmittel Rundschau 65: 144-147.

Suric, M. \& Joksimovic, J. 1973. A contribution to the investigations of pure and conjoint cultures of streptococci and micrococci in the ripening of sausages. Proc. XIX Eur. Meeting of Meat Res. Workers: 1629-1644. Paris.

Szczepaniak, B. \& Pezacki, W. 1974. Mikroflora variation in Polish raw smoked sausage during production and storage. Medycyna Weterynaryjna 30:278-282 (Ref. Food Sci. Technol. Abstr. 6 (1974) No. 10: 10 S 1411).

Ten Cate, L. 1960. De microbiologie der geschwitzte snijworst. Tijdschr. Diergeneesk. 85: $745-751$.

Urbaniak, L. \& Pezacki, W. 1975. Die Milchsäure bildende Rohwurstmikroflora und ihre technologisch bedingte Veränderung. Fleischwirtschaft 55:229-232, 235-237.

VALTONEN, V. V. 1970. Mouse virulence of salmonella strains: The effect of different smoothtype O side-chains. Journal of General Microbiology 64. 255-268. (Ref. V. Valtonen: Mouse virulence of salmonella, The role of lipopolysaccharide antigens, Helsinki 1972).

WALz, E. 1958. Die Einwirkung aerober Sporenbildner auf den Muskelfarbstoff. Arch. Lebensmittelhyg. 9: 200-203.

\section{SELOSTUS}

\section{Eräiden gram-negatiivisten bakteerien vaikutus kestomakkaran kypsymiseen ja laatuun.}

Esko PETÄJÄ

Helsingin Yliopisto, lihateknologian laitos

Gram-negatiivisten bakteerien mahdollista käyttöä starterkulttuureina kestomakkarassa tutkittiin siirrostamalla seuraavia gram-negatiivisia bakteereita kestomakkaraan yksinään ja Lactobacillus plantarumin kanssa: Aeromonas x, Aeromonas 19, Vibrio costicolus, Achromobacter guttatus, Achromobacter 22, Achromobacter X, Escherichia coli tai Proteus vulgaris. Ilman bakteerilisäystä valmistettuja makkaroita sekä mikrokokki + laktobasillilisäyksellä valmistettuja makkaroita käytettiin vertailunäytteinä tutkimuksessa. Kaksikymmentäkaksi koesarjaa kestomakkaraa valmistettiin ja tutkittiin kypsymisajan ollessa 21 vuorokautta. Seuraavia johtopäätöksiä voidaan tehdä bakteeri-inokulaatioiden vaikutuksista kestomakkaran kypsymisprosessiin ja laatuun: 
1. Ilman bakteerilisäystä valmistettujen näytteiden väri, konsistenssi, aromi ja maku olivat yleensä huonoimmat mikrokokki + laktobasillimakkaroiden ollessa paljon parempia ja jopa kilpaillen laadussa muiden koemakkaroiden kanssa. Mikrokokeilla ja laktobasilleilla siirrostettujen makkaroiden väri kehittyi kolmessa ja konsistenssi seitsemässä vuorokaudessa. Aromi ja väri olivat myös hyväksyttäviä viikon vanhoissa näytteissä. Mikrokokki pelkisti nitraattia kolmessa päivässä siten, että keskimääräinen nitriittimäärä nousi 34.1 ppm:ään ja laski sen jälkeen. Mikrokokkimäärä oli hieman yli $10^{7} / \mathrm{g}$ koko kypsymisajan, kun taas laktobasillimäärä kohosi $10^{7} / \mathrm{g}$ :sta $10^{8} / \mathrm{g}$ :aan kolmessa päivässä. pH-arvo laski kolmessa vuorokaudessa 5.70:sta 5.28:aan.

2. Kannat Aeromonas x ja Aeromonas 19 vaikuttivat suotuisasti kestomakkaran väriin, mutta muuten näytteiden laatu oli kontrollimakkaroiden tasoa. Aeromonas-kannat eivät muodostaneet makkaran laatuun vaikuttavia määriä happoa kestomakkarassa eivätkä siten parantaneet konsistenssia. Aromi ja maku olivat hieman parempia kuin kontrollimakkaroissa.

3. Aeromonas x ja 19 kannoilla oli varsin suotuisa vaikutus kestomakkaran laatuun laktobasillien kanssa inokuloituina. Molemmat kannat pelkistivät nitraattia värin muodostuessa kolmen ensimmäisen päivån aikana. Aeromonas + laktobasillimakkaroiden pH-arvo laski jopa nopeammin ja alemmaksi kuin mikrokokki + laktobasillimakkaroissa ollen noin $\mathbf{5 . 2 0}$ kolmen päivän kypsytyksen jälkeen. Aeromonas + laktobasillinäytteiden konsistenssi kehittyi yhdessä viikossa ja oli ainakin yhtä hyvä ja usein parempikin kuin mikrokokki + laktobasillimakkaroissa. Aeromonas $19+$ Lactobacillus-makkaroiden konsistenssi oli parempi kuin Micrococcus + Lactobacillus-näytteiden merkitsevyystasolla 0.05 . Aeromonas + laktobasillimakkaroiden aromi ja maku olivat yhtä hyviä tai parempia kuin mikrokokki + laktobasillinäytteiden. Aeromonas $19+$ Lactobacillus-makkaroiden aromi ja maku olivat merkitsevästi (merkitsevyystaso 0.001 ) parempia kuin Micrococcus + Lactobacillus-makkaroiden. Aeromonas $\mathrm{x}+$ Lactobacillus-näytteiden maku oli merkitsevyystasolla 0.05 parempi kuin Micrococcus + Lactobacillus-makkaroiden.

Kokonaisbakteerimäärä, vastaten suurinpiirtein laktobasillimäärää, oli usein merkitsevăsti suurempi aeromonas + laktobasillimakkaroissa (vaihteluväli $2-4 \times 10^{8} / \mathrm{g} \quad 3-21$ kypsytysvuorokauden aikana) kuin mikrokokki + laktobasillimakkaroissa (vaihteluväli $8 \times 10^{7}-1.5 \times 10^{8} / \mathrm{g} 3-21$ kypsytysvuorokauden aikana). Tästä syystä edelliset makkarat kypsyivät nopeammin kuin jälkimmåiset.

4. Vibrio costicolus ja kolme Achromobacter-kantaa eivät vain viihtyneet huonosti kestomakkarassa, vaan hävisivät täydellisesti seitsemän ensimmäisen kypsytysvuorokauden aikana. Pelkåstään Escherichia coli bakteerilla siirrostetut makkarat olivat laadultaan samaa luokkaa kuin kontrollimakkarat. Laktobasillien kanssa inokuloituna $E$. coli vaikutti paljolti mikrokokkien tavoin. Kuitenkin Micrococcus + Lactobacillus-makkarat olivat joka suhteessa hieman parempia kuin E. coli + Lactobacillus-makkarat. Proteus vulgaris vaikutti haitallisesti kestomakkaran laatuun sekä yksin että laktobasillien kanssa inokuloituna.

\section{Lop p u pä t e $1 \mathrm{~m}$ ä}

Tutkimus osoitti, että gram-negatiiviset bakteerikannat Aeromonas x ja 19 laktobasillien kanssa inokuloituna vaikuttavat edullisesti kestomakkaran laatuun. Etenkin Aeromonas 19 + Lactobacillus-inokulaation avulla saatiin parempaa kestomakkaraa kuin lisättäessä makkaraan mikrokokkeja ja laktobasilleja. 